\title{
KÖZÉPKORI ÉS 16-18. SZÁZADI VESZTŐHELYEK RÉGÉSZETE EURÓPÁBAN ÉS MAGYARORSZÁGON
}

\author{
KOVÁtS ISTVÁN*
}

\begin{abstract}
A medieval and post-medieval jurisdiction was essentially a public affair. The entire process of criminal action can be reconstructed from the written sources, the various depictions and historical town maps. The archaeology of law, one of the directions in European historical archaeology, is concerned also with the identification and excavation of places of punishment, and specifically with the archaeology of execution sites. In a broader sense, all material relics and sites associated with the execution of punishment and legal life can be assigned to this field of research. As a result of complex research projects, several medieval and post-medieval execution sites have been uncovered in Europe. Surveyed and discussed here are the research potentials of locating, identifying and excavating execution sites through examples taken from Europe and Hungary.
\end{abstract}

Keywords: medieval period, post-medieval period, jurisdiction, deviant burial, execution site

A középkor és kora újkor igazságszolgáltatása alapvetöen nyilvános volt. A bünvádi eljárások teljes folyamata rekonstruálható az irásos források, képi ábrázolások és várostérképek segitségével. Európában a történeti régészet egyik irányzata a kivégzőhelyek lokalizálását és feltárását is célzó jogrégészet, illetve ezen belül a vesztőhelyek régészete. Tágabb értelemben azonban ebbe a körbe tartozik minden, a korabeli büntetés-végrehajtással és jogélettel kapcsolatos tárgyi emlék és lelöhely. A komplex kutatási programok eredményeként több középkori és kora újkori vesztőhelyet tártak fel Európában. A tanulmány az esetlegesen vesztőhelyként azonositható lelóhelyeket és további hasonlók lokalizálásának és feltárásának lehetöségeit vizsgálja konkrét európai és magyarországi példák bemutatásával.

Kulcsszavak: középkor, kora újkor, igazságszolgáltatás, rendellenes temetkezések, vesztöhely

\section{A halálbüntetés jogi keretei a középkorban és a 16-18. században}

A középkor és a kora újkor időszakában ${ }^{1}$ a halálbüntetés minden országban általánosan alkalma-

A kézirat beérkezett: 2017. április 26.

* Kováts István. Magyar Nemzeti Múzeum - Mátyás Király Múzeum. 2025 Visegrád, Fő utca 23; kovatsistvan@visegradmuzeum.hu

1 A középkor és a kora újkor időszakának elválasztása a büntetőjogi jogfejlődés szempontjából a történeti-régészeti korszakhatárral ellentétben nem a 15-16. század fordulójára, zott büntetési nem volt; az ókor óta a legtöbb jogrendszerben rendes büntetésként (poena ordinaria) jelent meg. Az időszak büntetőjogi fejlődésének egyik fontos jellemzője - a korábbi, szokásjogon alapuló magánbosszú visszaszorulása mellett az állam által előírt és alkalmazott büntetések fokozatos térhódítása, majd kizárólagossá válása. Európában, akárcsak Magyarországon, a kiemelt büncselekmények büntetését írott jogforrások

hanem a 18. század második felére tehető. A halálbüntetések extenzív alkalmazása sokkal inkább jellemezte a kora újkort, mint a középkort. ТóтH J. 2010, 91. 
tartalmazták, ám ezek köre meglehetősen szúk volt; döntóen az államhatalom alapjait veszélyeztető cselekedetek tartoztak ide. A leggyakrabban elkövetett (köztörvényes) büntetteknek nem volt országos és írásban rögzített szabályozása: ezeket eltérő helyi szokásjogok alapján vagy statuálisan szankcionálták. Ebból következően az ítélkezés és az ítélet végrehajtása elsősorban a különböző szintú helyi bíróságok (például pallosjoggal rendelkező városi tanácsok és földesurak) feladata volt. Tovább bonyolította a kor jogéletét, hogy a középkori Európában tulajdonképpen kétfajta büntetójogi normarendszer létezett: a világi és az egyházi üldözés alatt álló búncselekmények, de az igazságszolgáltatás fontos részét képezték a 8-12. században virágkorukat éló istenítéletek (ordáliák), párbajok és eskük is. Noha a 16. század első felében az V. Károly császár által 1532-ben kiadott Constitutio Criminalis Carolina továbbra is széles körben lehetóvé tette mind a kínvallatás igénybevételét, mind a halálbüntetés alkalmazását, ezek feltételeit már írásban szabályozta, és ezzel egy bizonyos mértékú jogbiztonságot teremtett. ${ }^{2}$

Általánosságban elmondható, hogy - különösen a 16-17. században - nem csak az életellenes búncselekményeket, hanem sok más (vagyon elleni, erkölcsi, vallási stb.) vétséget is gyakran halállal toroltak meg. A végrehajtás módja szerint egyszerú (poenae capitales simplices) vagy minősített (poenae capitales qualificative) halálbüntetéseket különböztethetünk meg. Az előbbiek körébe tartozott a lefejezés, az akasztás vagy a kötél általi megfojtás, a kerékbetörés, vízbe fojtás, megégetés, megkövezés és a felnégyelés. Minősített büntetésnek számított a kerékbetörés súlyosbított formája, a horogra függesztés, a karóba, illetve nyársba húzás. A végrehajtás járhatott külön büntetési tételekkel is: ilyennek számítottak a kivégzést megelőző vagy azt követő csonkítások, az elítélt lófarkon hurcolása a vesztőhelyre, a holttestnek vagy egyes részeinek hosszabb-rövidebb ideig tartó közszemlére tétele, illetve temetőkön kívüli eltemetése vagy elégetése. ${ }^{3}$

A büntetések alkalmazásának elsődleges célja a megtorlás és elrettentés, valamint az elkövető számára a búnismétlés megakadályozása volt. Ugyanezeket a célokat szolgálta a gyakorlat is, hogy az ítéleteket (kevés kivételtól eltekintve) mindig nyilvánosan hajtották végre. A nyilvánosság a jogrendszer és a közösség számára egyúttal legitimálta a szankciókat, és jogbizton-

\footnotetext{
A kérdésről összefoglalóan: TóTH J. 2006, 68-75; 2010, 95-105. 3 BóDinÉ 2013, 31-45; 2014, 259-279; DÜLMEN 1990, 75-110, 150-151.
}

sági tartalommal is bírt; más szóval azok kétségbevonhatatlanságát bizonyította. ${ }^{4} \mathrm{~A}$ tudatos büntetésstatuálás teljes folyamatában a különböző szimbólumok és rituálék egész sorával egészült ki, amelyben vallási elemek és babonás szokások keveredtek. A 16-18. században ez a szertartás - melynek középpontjában az erőszakos halál liturgiája ${ }^{5}$ állt - még kötöttebb formákat öltött, sőt a 17. századtól egyre inkább látványos ünnepségekké kezdett válni. A testi büntetések rendszerét és a hozzá kapcsolódó ítélkezési és kivégzési rítusokat csak a 18. században, a felvilágosodás és a büntetójogi átalakulások idószakában kezdték el bírálni; a neves jogtudós, Cesare Beccaria hatására az itáliai Toscanában szüntették meg elsőként a halálbüntetést 1765-ben. ${ }^{6}$ Ennek ellenére Európa legtöbb országában egészen a 19. századig részben uralkodó büntetési forma maradt.

A halálbüntetések számának ugrásszerú növekedése és a minősített végrehajtások gyakori alkalmazása a 16-17. században összetett okokra vezethető vissza. Az időszak kriminalisztikai öszszesítéseiben ${ }^{7}$ kimutathatóan megnótt nemcsak a tulajdon ellen elkövetett, hanem az erőszakos büncselekmények száma is; vagyis területenként és régiónként eltérő mértékben ugyan, de általánosan romlott a közbiztonság. A hatóságok többek között erre a jelenségre is reagáltak - részben a társadalom elvárásainak megfelelően - a büntetőgyakorlat szigorításával. Egyes magyarázatok szerint az erőszak elharapózásának fó okai elsősorban a 16-17. századi negatív éghajlatváltozásban (kis jégkorszak), illetve ebből következően a gazdasági erőforrások kimerülésében és az időszak nagy mortalitási kríziseiben mutatkoznak meg, amelyek a politikai, vallási és társadalmi konfliktusok kiéleződéséhez vezettek. ${ }^{8}$ A kegyetlenség legalizált formáinak - nyilvános kivégzések, megszégyenító és testi büntetések elterjedéséról és az azokat kiváltó okokról a 16. századi városi társadalmakban írásos forrásokból is értesülünk. ${ }^{9}$

A magyarországi jogfejlődésben ${ }^{10}$ az európaihoz hasonló folyamatok figyelhetők meg. Az első törvényekben csupán egyes büntetójogi alapintézmények és fogalmak kezdetleges megjelenése mutatkozik meg - ezeknél külföldi példák követése is feltételezhető. Szent István törvényei bizo-

\footnotetext{
То́тн J. 2006, 69-70.

DÜLMEN 1990, 140-156.

6 То́тн J. 2010, 117-119.

DÜLMEN 1990, 206-213.

BEHRINGER 2010, 149-153, 166-176.

SZEGHYOVÁ 2004, 167-190.

10 Összefoglalóan lásd Tóтн J. 2010, 187-321.
} 
nyos esetekben intézményesítették a halálbüntetést, Szent László pedig a lopás egyes nevesített eseteire terjesztette ki, mégis úgy túnik, hogy a 10-13. században viszonylag kevéssé volt jellemző. ${ }^{11} \mathrm{~A}$ későbbiekben az európai tendenciákat követve ${ }^{12}$ egyre elterjedtebbé vált Magyarországon is; szokásjogi alapon elsősorban a vármegyei törvényszékek (sedriák) és a pallosjoggal (ius gladii) vagy „vérhatalommal” rendelkezó úriszékek és városok ítélkezési gyakorlatában alkalmazták. ${ }^{13}$ A 14. századtól ugyanis megjelentek a büntetőjogi jogforrások között azon privilégiumok, amelyek egyes városoknak vagy földesuraknak büntetó joghatóságot biztosítottak polgáraik, szolgáik, jobbágyaik felett. E kiváltságlevelek a törvények által nem szabályozott büntetójogi kérdések esetében a kedvezményezettek számára lehetővé tették, hogy a városok és földesurak a helyi szokásjogi szabályok alapján ítélkezhessenek, valamint azt, hogy saját maguk is alkothassanak új büntetőjogi normákat. Ez egyes búntettek halállal való büntethetőségére is kiterjedt. ${ }^{14}$ A $16-17$. században elsősorban a német-osztrák joggyakorlatból kerültek át a minősített halálbüntetési nemek, ${ }^{15}$ és a végrehajtott kivégzések száma is lényegesen megnőtt. A Werbőczy István nádor által 1514-ben kiadott szokásjogi gyújtemény (Hármaskönyv, Tripartitum), bár írásban rögzítette a halállal fenyegetett cselekményeket, a korábbi évszázadok jogi rendszertelenségét nem tudta megszüntetni; az írott jog viszonylagos kiszámíthatóságot csak a III. Károly nevéhez köthetó 1723. évi igazságügyi reformmal kapott. Ennek ellenére a szokásjogi szabályozás még a 18. században is érvényesült, bár a század második felétől egyre ritkábban. A felvilágosult abszolutizmus korában, Mária Terézia és II. József uralkodása alatt a magyar büntetőjogi gyakorlat egyre humánusabb lett: korlátozták, majd meg is szüntették a kínvallatást és a nyilvános halálbüntetéseket, és a büntetési rendszer alapjává a szabadságmegvonást (börtön, közmunka, hajóvontatás) igyekeztek tenni. ${ }^{16}$ Mindezek a változtatások azonban csak hosszas folyamatok eredményeképpen léphettek életbe; vesztőhelyeken végrehajtott kivégzések (elsősorban akasztás és fóvétel útján) még a 19. században is előfordultak.

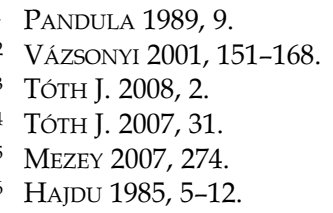

\section{A jogi kultúrtörténettől a vesztőhelyek régészetéig}

A jogi kultúrtörténet olyan határterületi, de egyben rendkívül összetett tudományág, amely a jogtörténeten alapul, de vizsgálata elképzelhetetlen az általános történelemtudományok (múvészettörténet, régészet, néprajz, múvelődéstörténet, vallástörténet) és a történelmi segédtudományok (heraldika, szfragisztika, inszigniológia, ikonográfia) nélkül. Tárgya tehát tágabb értelmezésben minden olyan információhordozó (írásos forrás, múvészeti alkotás, régészeti lelet stb.), amelynek a jog szempontjából történeti forrásértéke van. A német jogtörténeti irodalomban az ilyen irányú vizsgálódások 19 . századi megjelenése óta több rokon értelmú fogalom alakult ki: Rechtsaltertum (jogi régiség), Rechtsarchäologie (jogrégészet) és Rechtssymbolik (jogi szimbolika). ${ }^{17}$ A jogrégészet elsősorban a korabeli jogélet tárgyi emlékeinek (hivatali jelvények, kivégzőés kínzóeszközök stb.) és helyszíneinek (tanácsházák, üléstermek, börtönök, pellengérek, vesztóhelyek stb.) kutatását célozza; a fogalmat elsőként 1890-ben Karl von Amira német jogtörténész használta, aki ezzel a jogtörténeti kutatás teljesen új ágát alapította meg. ${ }^{18} \mathrm{~A}$ képi és írásos források elemzésén túlmutató, az egykori jogélet, ítélkezés és ítélet-végrehajtás tárgyi emlékanyagának és helyszíneinek a teljesség igényével való gyújtése és értelmezése a későbbiekben Hermann Balt ${ }^{19}$ és Witold Maise ${ }^{20}$ munkáiban is erôteljesen megjelent. A kezdetektól kiemelkedő fontosságú volt az európai népi jogszokások vizsgálata és összehasonlítása, amely idővel a jogi néprajz szakterületévé vált. ${ }^{21}$

Hagyományos régészeti módszerek alkalmazásával már a 19-20. században is számos esetben kerültek elő a középkor jogéletével - elsősorban büntetés és ítélet végrehajtásával - kapcsolatba hozható leletek és objektumok. Egy részük más korszakok lelóhelyeinek ásatása folyamán véletlenszerúen vált ismertté; az őskori temetkezési halmok, tell-települések és magaslati erődítmények kiemelkedő terepalakulatain a későbbi időszakokban gyakran vesztőhelyeket létesítet-

7 KAJTÁR 2004, 28; 2006, 131.

8 LÜCK 2012, 37.

19 BALTL 1957, 59-131. A jogrégészeti munkára Laszlovszky József (CEU, Department of Medieval Studies) hívta fel a figyelmemet, a kötethez való hozzáférést Újhelyi Nóra (CEU, Department of Medieval Studies) biztosította, amiért mindkettejüket köszönet illeti.

20 MAISEL 1993, 111-167.

21 MeZey-Nagy 2009. 
tek. ${ }^{22}$ Ezek azonosítását az is lehetővé tette, hogy a hosszabb-rövidebb ideig folyamatosan használt kivégzóhelyek vagy azok egyes elemei - például az akasztófák kőalapozásának vagy felmenó falazatának omladozó maradványai néhol még a 20. század első felében is láthatóak voltak. ${ }^{23}$ Mindazonáltal a korai ásatások eredményeinek összegzése, a megfigyelt jelenségek rendszerbe foglalása, keltezésük pontosítása az esetek döntő többségében csak jóval később valósult meg. ${ }^{24}$

A vesztőhelyek régészete (Richstättenarchäologie) önálló, interdiszciplináris szakterületként viszonylag későn, az 1990-es évektől, elsősorban nyugat- és közép-európai területeken vált a történeti régészet (post-medieval archaeology) egyik újabb kutatási irányává. ${ }^{25}$ Ebben az idószakban egyes lelőhelyek célzott, teljes körú ásatása és dokumentálása mellett ${ }^{26}$ olyan, a témakört érintó komplex összefoglalások is születtek, amelyek a régészeti feltárásokból származó leletanyag mellett az írott források, képi ábrázolások és kartográfiai adatok szerepét is különösen hangsúlyosnak tekintik. ${ }^{27}$ Ujj szakaszt jelentett a kutatás történetében Jost Auler tevékenysége, aki az irányzat eddigi európai eredményeit több szakcikkben és az általa szerkesztett tanulmánykötetekben öszszegezte. ${ }^{28}$

A jogrégészeti alapokon kialakuló és fejlődő szakterület nem csak a szúkebb értelemben vett vesztőhelyekre és azok közvetlen környezetének vizsgálatára irányul. Ebbe a körbe sorolható az ítélkezéssel és ítélet-végrehajtással kapcsolatba hozható minden lelet vagy objektum (pl. pellengérek, szégyenoszlopok maradványai). Kiemelt jelentőségúek a kivégzőhelyeken vagy azok közvetlen környezetében felbukkanó, általában szabálytalan helyzetú temetkezések, kisebb sírcsoportok vagy egyes sírok, illetve az antropológiai módszerekkel a csontmaradványokon megfigyelhető, erőszakos halálra, testi fenyítésre utaló vagy az egykori procedúra részeként post mortem keletkezett traumás sérülések is. ${ }^{29} \mathrm{~A}$ többnyire a

22 Például Wor Barrow (Dorset) lelőhelyen egy neolitikus halom Pitt Rivers által 1893-1894-ben végzett feltárása közben vagy Meon Hill (Hampshire) vaskori erődjének területén 1932-ben: REYNOLDS 2009, 113-117.

23 BALtL 1957, 78-79, VII. tábla: 22-23. kép; SOKOL 2003, 751, 17-18. kép; AULER 2008, 21, 4. kép.

24 AULER 2008a, 12-45; 2010, 12-28; 2012, 24-35; REYNOLDS 2009, 97-179.

25 AULER 2013, 139-149.

26 SOKOL 2003, 759-760; PIECH 2008, 230-248.

27 КRAвATH 2008, 152-168; SOKOL 2008a, 496-505; 2010, 348-374

28 Vö. AULER 2008; 2010; 2012.

29 PIePer-SChlÜter 2008, 388-412; BosChleR-LANZ 2008, 412436. települések perifériáján fekvő vesztőhelyeket gyakran használták állati tetemek megsemmisítésére vagy elföldelésére; az állatmaradványok archaeozoológiai szempontú értékelése ${ }^{30}$ hasznos információkat szolgáltathat e területek másodlagos hasznosításáról. A diszciplína összetettségét mutatja, hogy a korabeli temetkezési gyakorlat - gyakran büntetésekhez, kiközösítéshez kapcsolódó népi hiedelmek és babonák által is befolyásolt - sajátos jelenségeinek (közösségi temetőktől elkülönült vagy azokon belüli, gyakran rendellenes helyzetú sírok és sírcsoportok) értelmezésében sem mellőzhetők a vesztőhelyek régészeti kutatásainak eredményei. ${ }^{31}$

A magyar büntetésügy múltjának feltárása a korai időszakban elsősorban Vajna Károly nevéhez fúződik. A jogakadémiát végzett Vajnát történeti érdeklődése és hivatása - 1901-től a Budapesti Országos Gyújtőfogház igazgatója volt - egyaránt arra sarkallta, hogy minél szélesebb körben összegyújtse, majd közzétegye a hazai büntetés-végrehajtás történetének emlékeit. Az évekig tartó, különösebb előzmények nélküli gyưjtőmunka eredménye a Hazai régi büntetések címú kétkötetes monográfia lett, amely 1906-1907-ben jelent meg. A monumentális mú nem pusztán a magyarországi polgári jogrendszer bevezetése előtti igazságszolgáltatást mutatja be; bőséges forrásanyag alapján ismerteti a börtönbüntetés, ${ }^{32}$ a testi fenyítések ${ }^{33}$ és a halálbüntetések ${ }^{34}$ gyakorlatát, helyszíneit, jellemzőit és eszközeit is. Ebben a vonatkozásban Vajna munkássága teljességgel megfeleltethető a jogrégészet európai irányainak; múve lényegében napjainkig alapvetó forrásmunkának tekinthető. Idekívánkozó további adalék, hogy a birtokába került és a hazai gyújtemények által adományozott nagy mennyiségú tárgyi anyagból 1910-ben új közgyújtemény, az Országos Börtönügyi Múzeum jött létre. A több ezer tételből - bírói jelképek, kivégző- és kínzóeszközök, rabmunkák, búnjelek stb. - álló, a szélesebb nyilvánosság elől elzárt múzeum anyagát a II. világháborúban súlyos károk érték. A megmaradt, zömmel újkori tárgyak nagyobb része a későbbiekben Kiskunfélegyházára került, ahol a Kiskun Múzeumban 1969-ben állandó tárlat nyílt a Magyar büntetőjog emlékei címmel. ${ }^{35}$

30 Deschler-Erb-Stopp 2006; Motschi et al. 2008, 206-230.

31 Összefoglalóan lásd DuMA 2010; 2015. A szerzőnek külön köszönöm a témában nyújtott széles körú tájékoztatását.

32 VAJNA 1906, 27-696.

33 VAJNA 1907, 73-165.

34 VAJNA 1907, 165-247.

35 NÁNÁSI 2012, 31-33. 


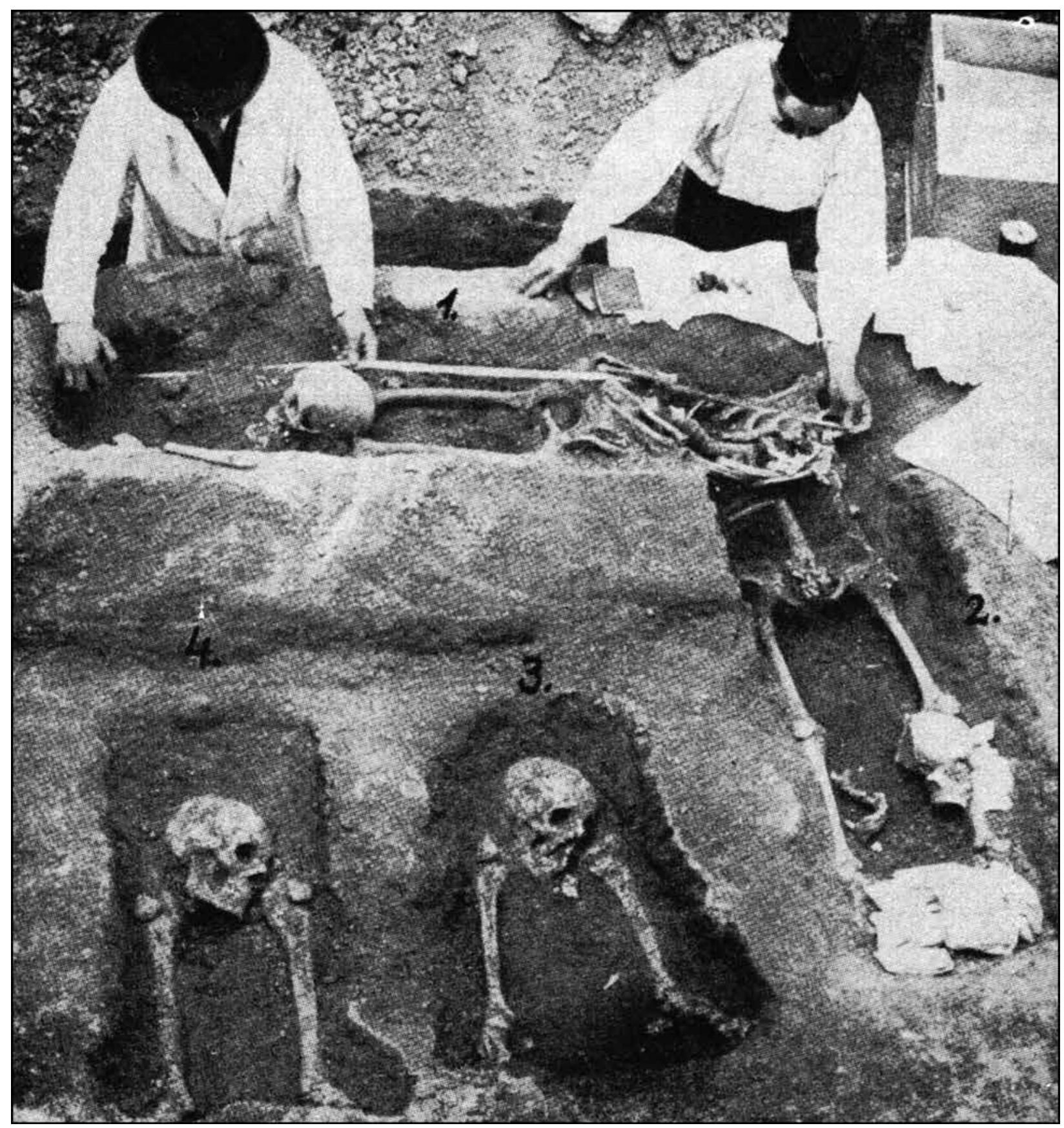

1. kép. A magyar jakobinusok sírjainak feltárása 1914-ben (BARTUCZ 1966, 456, 247. kép nyomán)

Fig. 1. Excavation of the graves of the Hungarian Jacobins in 1914 (after BARTUCZ 1966, 456, Fig. 247)

Vajna tevékenységével egy időszakra tehető az 1795-ben fővesztés útján kivégzett magyar jakobinusok sírjainak feltárása (1. kép). Igaz ugyan, hogy az 1914-ben Bartucz Lajos antropológus által elvégzett ásatást és személyazonosítást, majd a maradványok többszöri újratemetését elsődlegesen kegyeleti (és időnként) politikai szempontok motiválták, mégis ez tekinthető a modern értelemben vett vesztőhelykutatás hazai előzményének. Noha a kivégzés helyszínét (a budai Várhegy nyugati lábánál elterülő Vérmezőt) és lefolyását rendkívül alaposan dokumentálta a nagyszámú fennmaradt korabeli leírás és ábrázolás, szinte semmit nem lehetett tudni az áldozatok nyugvóhelyéről. Éppen ezért a temetkezések pontos helyének azonosítása igen sokoldalú kutatással vált lehetővé. A sírhelyek régészeti módszerekkel történt feltárásának, a jelenségek gondos in situ rögzítésének, továbbá az antropológiai vizsgálatok során tett megfigyelé- 


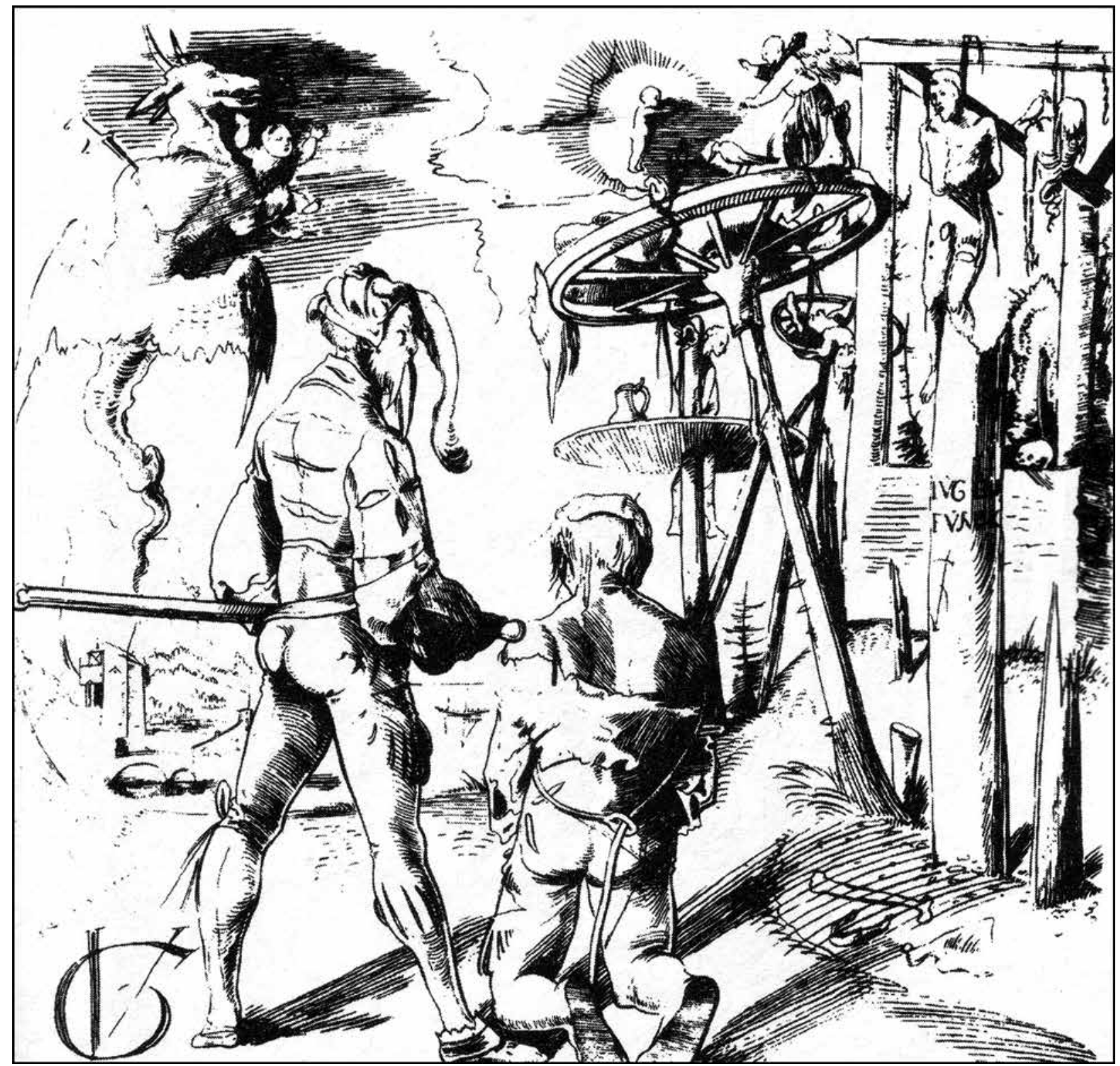

2. kép. Vesztőhely Urs Graf fametszetén, 1513 (KELLER 1921, 65 nyomán)

Fig. 2. Execution site on Urs Graf's woodblock, 1513 (after KeLLER 1921, 65)

seknek köszönhetóen sikerült a régészet és az alkalmazott természettudományok oldaláról is megerősíteni és igazolni egy múltban lezajlott kivégzés minden részletét. ${ }^{36}$

Annak ellenére, hogy szórványos régészeti adatok a 20. század első felében is vannak vesztőhelyek előkerüléséről, ${ }^{37}$ a középkori és kora újkori büntetésrendszerek és ítélet-végrehajtás helyszíneinek, szereplőinek, módszereinek, eszközeinek, szimbolikájának stb. kutatása első-

\footnotetext{
36 BARTUCZ 1966, 445-519.

37 NAGY 1943, 374.
}

sorban a jogtörténészek szakterülete maradt. ${ }^{38}$ Összegzéseik igen sok vonatkozásban érintik a korabeli halálbüntetések - így a vesztőhelyek kérdéskörét is, mégis elmondható, hogy a tárgyianyagi kultúra összefüggésében e témában született munkák száma lényegesen kisebb. Ezek is elsősorban múzeumi gyújteményekben megőrződött tárgyakat ismertetnek, ${ }^{39}$ és inkább a fenn-

38 A rendkívül gazdag irodalomból kiemelve: a kivégzés folyamatairól és rituáléjáról lásd DÜLMEN 1990, 92-127, 140-155; KAJTÁr 2004, 61-73; BódiNÉ 2013, 31-45; 2014, 259-274. A börtönről és viszonyairól: MeZEY 2010, 27-161. A hóhér szerepéról: KeLLER 1921; DAVIDOVICS 2006, 46-64.

39 ЈАКАВ 2009, 377-383. 
maradt gazdag képi és írott forrásanyag segítségével mutatják be a korabeli büntetés-végrehajtás világát. ${ }^{40}$ Tény, hogy csak nagyon kevés - ásatásokból is származó ${ }^{41}$ - emlékanyag maradt fent; az 1986-ban az egri Dobó István Vármúzeumban megnyílt, majd 1998-ban felújított, tudományos igénnyel rendezett kiállítás is kizárólag mútárgymásolatokat mutat be. ${ }^{42}$

Az utóbbi idóben egy-egy település vonatkozásában történeti-régészeti szempontú vizsgálatok is folytak vesztőhelyek lokalizálására. A hódoltság kori Szolnok esetében a különböző forráscsoportok együttes figyelembevételével sikerült nagy valószínúséggel meghatározni a várostól északnyugatra, a Hatvanba vezetô út mentén azóta már beépített területen fekvő kivégzőhelyet. ${ }^{43}$ Körmend büntetés-végrehajtási objektumait Siklósi Gyula gyújtötte össze; munkájában a történeti-topográfiai adatok mellett a régészeti megfigyelések fontosságát is hangsúlyozta. ${ }^{44}$ Újabban a vesztőhelyrégészet témájában egyetemi szakdolgozat is született, amelynek szerzője egy adott régió (Vas megye) kora újkori vesztőhelyeinek azonosítására tett kísérletet az önálló történeti-térképes adatgyújtés mellett térinformatikai módszerekkel is. ${ }^{45} \mathrm{Ez}$ a munka nem csak az interdiszciplináris jelleget erősíti, de jelzi azt is, hogy az irányzat kutatásában komoly tudományos tartalékok és lehetőségek rejlenek.

\section{A vesztőhelyek általános jellemzői}

A középkori és kora újkori vesztőhelyek fó jellemzőit e helyütt csak általánosságokban foglalhatjuk össze. A 18. századi igazságügyi reformok bevezetése előtti időszakban sok város, hatóság, személy rendelkezett pallosjoggal, amely természetesen nemcsak kard általi halálos ítélet meghozatalára, hanem az összes szokás- és jogszerúen alkalmazott halálnem kimondására feljogosított. ${ }^{46}$ A kivégzés szertartásának középpontjában a bitó, illetve a vesztőhely állt (2. kép), amely a pallosjog jelképeként gyakran a bírósági kerület határát is jelölte, illetve a pellengérrel együtt

40 TEMESVÁRY 1970.

41 TEMESVÁRY 1970, 3.

42 PANDUla 1989.

43 KertÉsz 2012, 54-60. A tanulmányra Feld István (ELTE BTK Régészettudományi Intézet, Magyar Középkori és Kora Újkori Régészeti Tanszék) hívta fel a figyelmemet, akinek segítségét ezúton is köszönöm.

44 SIKLÓSI 2005, 22-23.

45 BALOGH 2016. A szerzőnek e helyütt szeretnék köszönetet mondani a kéziratba való betekintésért, valamint a rendelkezésemre bocsátott irodalomért és a témában folytatott hasznos konzultációkért.

46 DAVIDOVICS 2006, 47. szimbolizálta a város bíráskodási jogát. ${ }^{47}$ Ezek a létesítmények elhelyezkedhettek az adott településeken belül (inter muros) és azokon kívül (extra muros, extra civitatem) is. ${ }^{48} \mathrm{~A}$ belterületen, általában valamely központi, forgalmas helyen (városháza, piac) felállított, fából ácsolt vérpadot többnyire csak ideiglenes jelleggel, alkalmanként használták. ${ }^{49} \mathrm{Az}$ állandó kivégzőhelyek a városok szélén, zömmel magaslati pontokon, az utaktól, útkereszteződésektől, városkapuktól belátható távolságra feküdtek (3. kép). ${ }^{50}$ Legfontosabb és legjellegzetesebb objektumaik az akasztófák voltak. Feltételezik, hogy ezek német eredetú elnevezése (Galgen) az ágat, gallyat jelentő régi 'galgo' kifejezésből származik, és egyben azt is jelzi, hogy az akasztásokhoz kezdetben fákat használtak fel. ${ }^{51} \mathrm{~A}$ későbbiekben a gerendákból emelt bitófáknak számos, különböző változata kialakult: az általában 1-4 oszlopból álló ${ }^{52}$ építmények mellett megjelentek a részben vagy egészben kőből és téglából épült, masszív kialakítású vesztőhelyek $^{53}$ és kőoszlopos akasztófák, amelyek hosszú ideig meghatározó elemei voltak a tájnak. A 14. századot megelőző időszakból ilyenek nem ismertek; ${ }^{54}$ tömeges építésük és használatuk elsősorban a 16-18. század közé eső időszakra tehető. ${ }^{55}$

Az állandó, hosszú időszakon át használt, tartós anyagból épített, a környezetből kiemelkedő vesztőhelyek többnyire kör vagy ovális alakban ${ }^{56}$ elrendezett (4. kép), átlagosan 5-7 méter külső átmérőjü, 2-3 méter magas, 80-120 cm széles felmenő falazattal rendelkező ${ }^{57}$ emelvények voltak, amelyen a bitófák álltak; a szerkezet teljes magassága így elérte az 5-7 métert. Ismert a három-

47 DÜLMEN 1990, 88-89

48 TRZCIŃSKI 2001, 190-191.

49 A 15. század első felében keletkezett Budai Jogkönyv (Ofner Stadtrecht) adatai szerint Budán közvetlenül a városháza mellett a Főpiacnak a Káposztáspiac elnevezésú részén és a Szent György-kápolna mellett történt az ítélet-végrehajtások egy része, és itt állt a pellengér is. Az akasztások a városkapukon kívül folytak. Idézi: BENDA 2011, 85.

50 DÜLMEN 1990, 88-89; SOKOL 2008, 496.

51 TRZCIŃSKI 2001, 158; BÓDINÉ 2014, 265.

52 EVERS 2008, 447-454.

53 A különböző konstrukcióknak összesen hét nagyobb típusát különítették el. KRABATH 2008, 156-163.

54 SOKOL 2003, 766.

55 Megjegyzendő, hogy már viszonylag korai időszakban is emeltek többoszlopos, bonyolult struktúrájú akasztófákat. Az egyik legismertebb ezek közül a IX. Lajos király idején a 13. században létrehozott kétszintes, 16 oszloppal rendelkező, a későbbiekben kőből újraépített és bővített párizsi bitó volt, amelyet a 17. századig folyamatosan használtak. TRZCIŃSKI 2001, 185.

56 SOKOL 2003, 742-750, 3-16. kép; DuMA 2015, 172-187, 28-30, 40-53. kép.

57 SOKOL 2003, 751-755; DUMA 2015, 227. 
szög, 58 illetve az ábrázolások alapján gyakori lehetett a négyszög59 alaprajzú építmény is. A kivégzőhelyek sajátos megjelenési formája volt az akasztófák nélküli, szintén változatos alakú ún. 'hollókő' (Rabenstein), amelyen elsősorban a lefejezéseket hajtották végre. ${ }^{60} \mathrm{~A}$ gyakran külső vagy belső lépcsővel, esetenként beltéri kamrával ${ }^{61}$ rendelkező vesztőhelyeknek néhol zárható bejáratuk is volt. Egyes vélemények szerint ez részben a hóhér védelmét biztosította, másrészt megakadályozta a kivégzettek holttestéhez való illetéktelen hozzáférést is. ${ }^{62}$

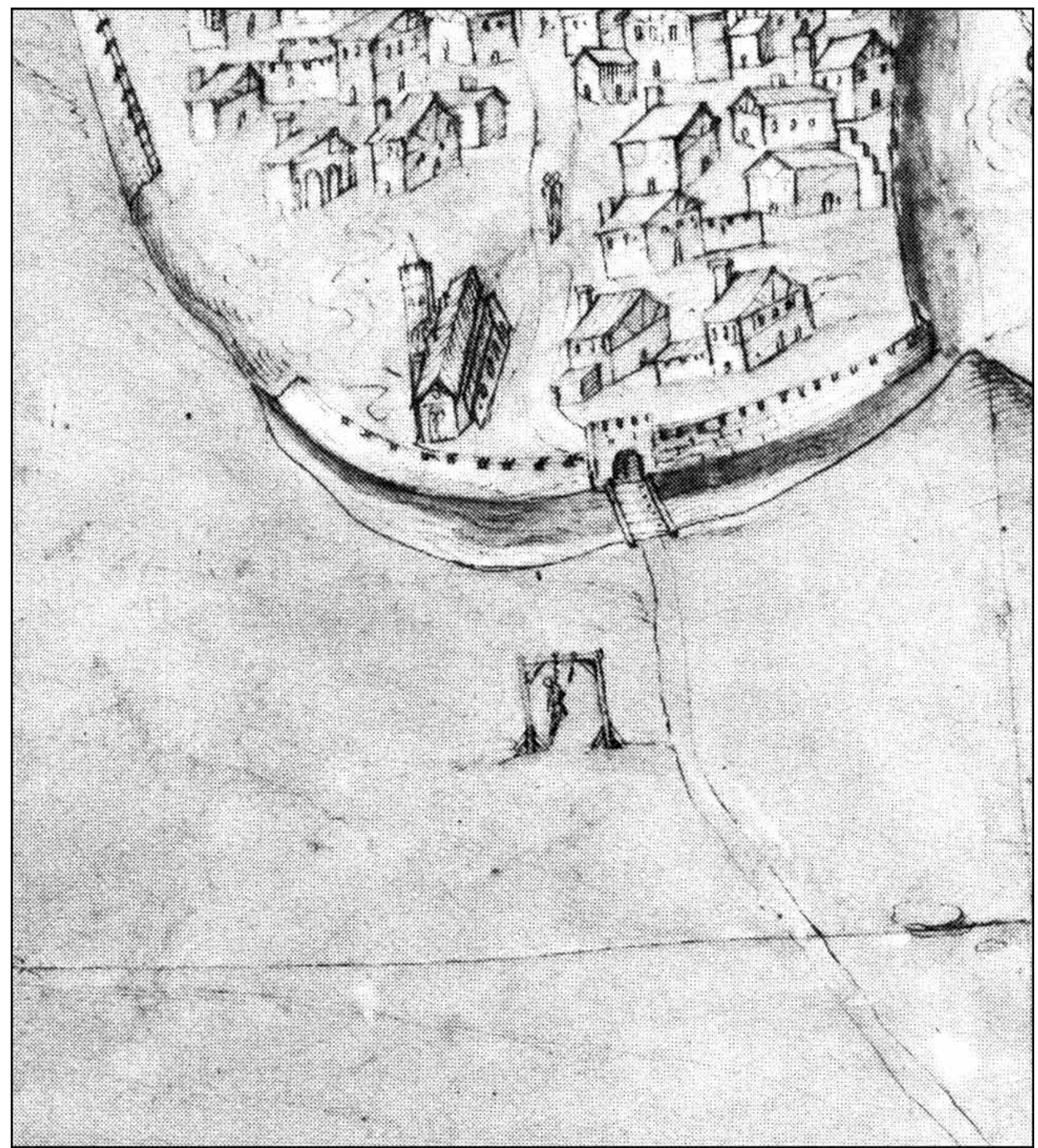

3. kép. Városkapun kívüli vesztőhely Scarborough 16. századi várostérképén (PlATT 1976, 179, 121. kép nyomán)

Fig. 3. Execution site beyond the town gate on the 16th-century map of Scarborough (after PLATT 1976, 179, Fig. 121)

58 SOKOL 2003, 759, 25. kép; AULER 2008b, 290, 3. kép.

59 Auler 2008c, 81; KRABATH 2008, 162-163, 8-10. kép.

60 WојтUскI 2010, 394-409.

61 SоKOL 2003, 759

62 SOKOL 2003, 751. 


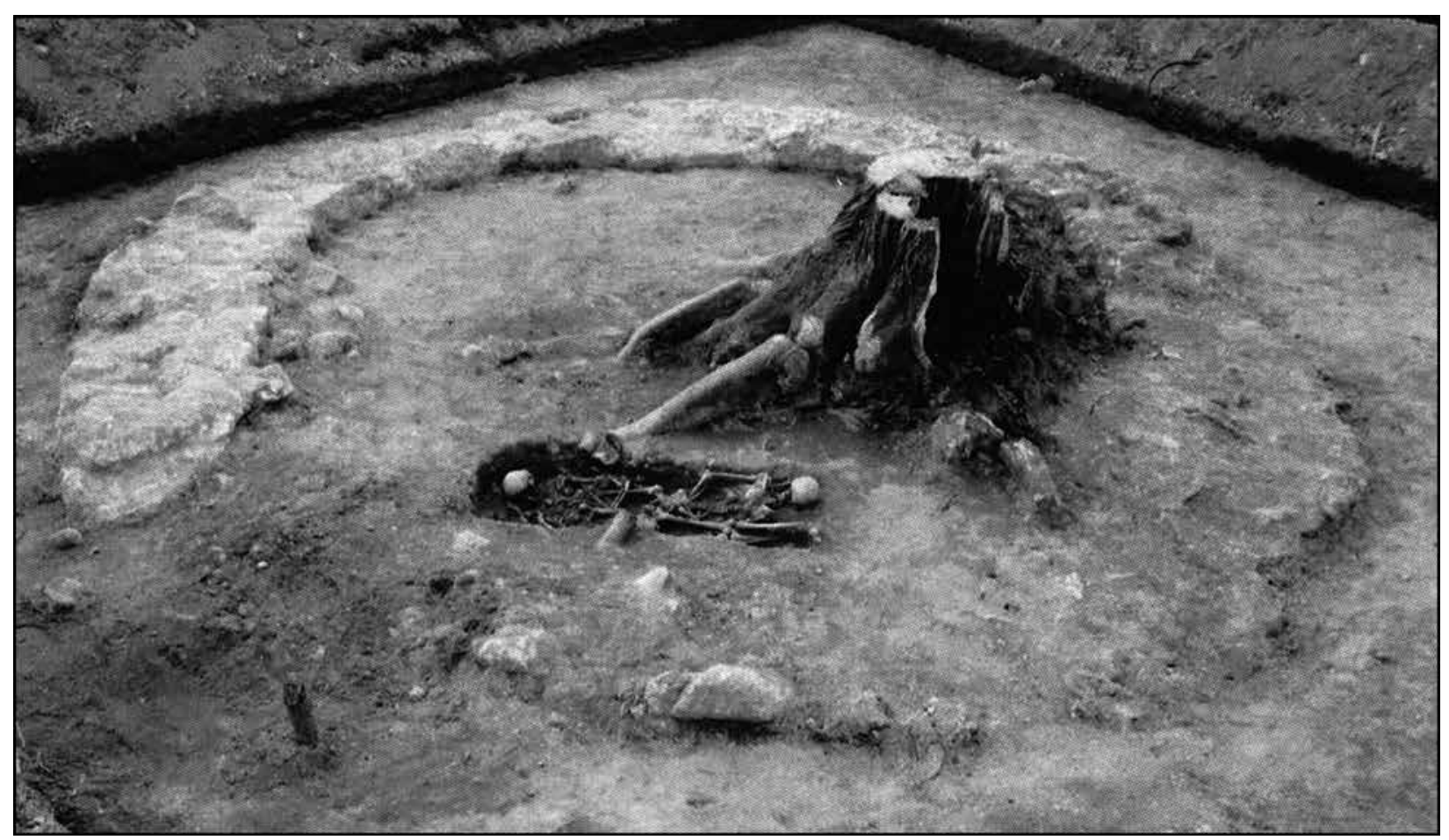

4. kép. Ítéletvégrehajtó-hely kőalapozása a lengyelországi Lubomierzben (DuMA 2015, 173, 29. kép nyomán)

Fig. 4. Stone foundation of an execution site in Lubomierz, Poland (after DuMA 2015, 173, Fig. 29)

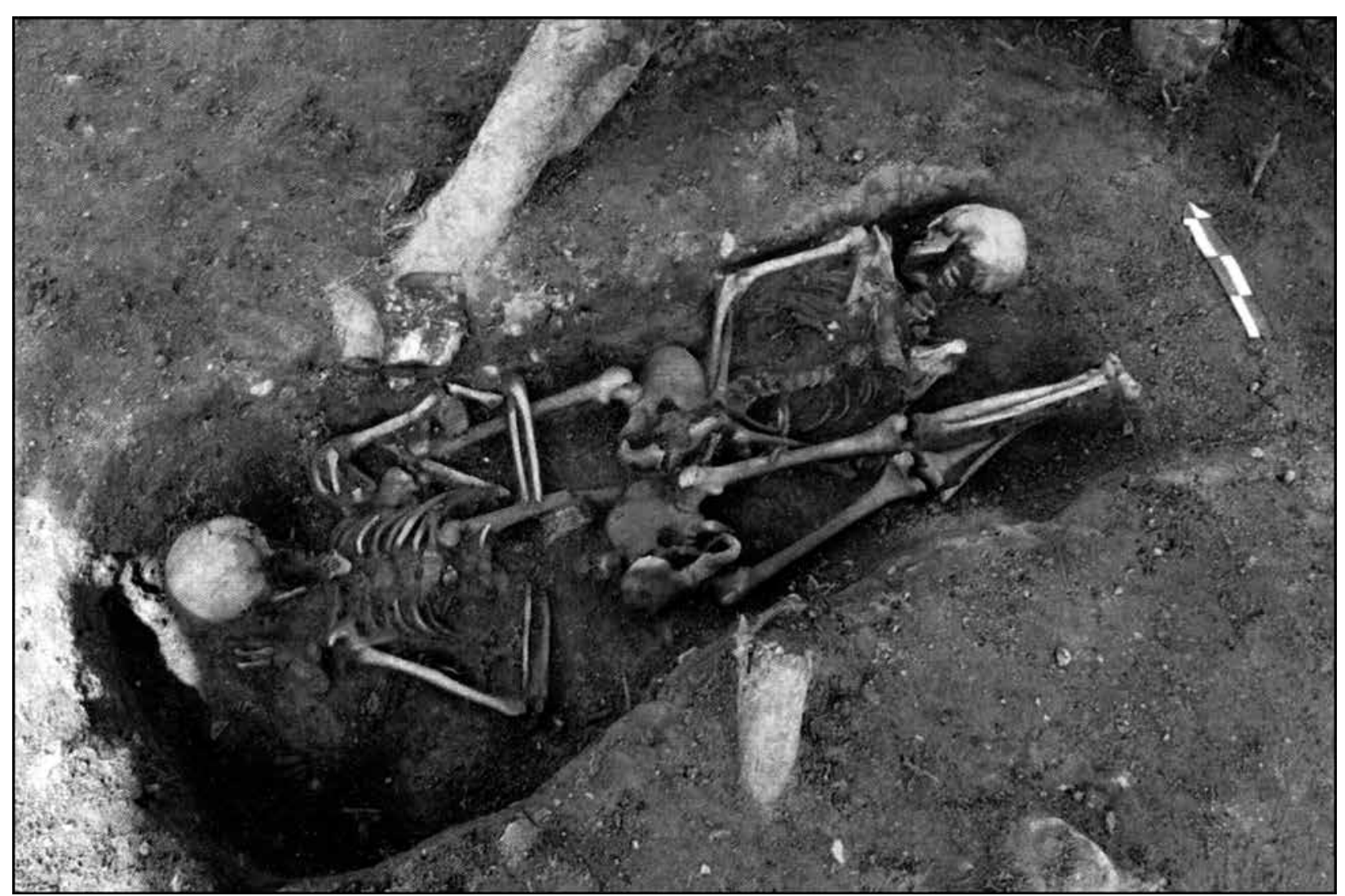

5. kép. Rendellenes helyzetú temetkezések feltárása a lengyelországi Lubomierzben (DuMA 2015, 174, 32. kép nyomán) Fig. 5. Excavation of deviant burials in Lubomierz, Poland (after Duma 2015, 174, Fig. 32) 
Írásos források is megerősítik, hogy egy-egy kivégzőhely felépítése, ${ }^{63}$ karbantartása és fenntartása helyenként nagyon komoly anyagi ráfordításokat igényelt. ${ }^{64}$ Ezért nyilvánvaló, hogy nem minden pallosjoggal rendelkező településnek állt módjában ilyen mértékú építkezés. Mégis, a hatóságoknak általában érdekük volt állandó vesztőhelyeket létesíteni, hiszen ezzel nemcsak az igazságszolgáltatás erejét, hanem a városi tanács hatalmát is demonstrálni tudták. ${ }^{65}$

A fenti adatokat a régészeti kutatások több ponton is alátámasztották. Az általában 16-18. századra keltezett, hosszú ideig használt kővagy kőalapozású objektumokon kívül a fából készült akasztófák legáltalánosabb nyomai a több helyen megfigyelt, szabályos elhelyezkedésú cölöpgödrök és gerendalyukak; ;6 ezeknek egészen korai időszakból származó (9-11. század), két- és négyoszlopos konstrukciókra utaló nyomait is azonosították. ${ }^{67}$ Elóbukkantak a faoszlopok kó- és téglaalapozásai és kőbitó lábazati részének töredékei is. ${ }^{68}$

A vesztőhelyek csaknem minden lelőhelyen előforduló jelenségei a részleges vagy teljes, rendszerint szabálytalan fekvésú emberi csontvázak (5. kép). Mennyiségük igen eltérő lehet (ismert csaknem 200, egyértelmúen kivégzéshez köthetó temetkezés is), ${ }^{69}$ de többnyire kis sírszámú lelőhelyekről van szó. A sírokra általánosan jellemző a teljesen esetleges tájolás, az eltérő, de sok esetben sekély sírmélység, a magányos és csoportos temetkezés is. Gyakori az arccal földnek fordított, oldalra fektetett, zsugorított helyzetú, hátrakötött kezú és egyéb változatos pozíciójú „véletlenszerú" eltemetés, a sírmellékletek teljes hiánya, illetve az erőszakra utaló traumás sérülések viszonylag magas előfordulási aránya. ${ }^{70}$ További ismérvük, hogy a kíséró leletanyag általában minimális. Nagy többségük ruhatartozék (gombok, övcsatok, kapcsok), illetve

63 Neuss város (Észak-Rajna-Vesztfália) hollókövéhez például 125000 téglát használtak fel: WOJTUCKI 2010, 401.

$64 \mathrm{Az}$ Eichstatt melletti Dollenstein új bitófájának felállítása 1523-ban 34 forintba került; a költségeket az egész járás gazdái és zsellérei, valamint azok családtagjai fedezték: DüLMEN 1990, 90. Halle városa 1534-ben pénzbeli lehetőségek hiányában nem tudott új falazott akasztófát építeni, ezért csak a régit javították meg: TRZCIŃSKI 2001, 187.

65 Ezt az akasztófa építését kísérő szertartások, illetve a helyenként igen fényúző bitóavatási ünnepségek is jelzik, amelyekre szintén jogszimbolikai aktusként került sor: DÜLMEN 1990, 89-90.

66 MAŠKOVÁ-MiCHÁLEK 2006, 804.

67 ReYNOLDS 2009, 158-159.

68 PIECH 2008, 233-237.

69 REYNOLDS 2009, 139-142.

70 Busch 2008, 99-103; GENESIS 2008, 145-149; REYNOLDS 2009, 159-177; DUMA 2015, 168-171, 174-176. egyéb kisebb tárgy (kerámiatöredékek, vaskés, ácskapcsok, szögek, rózsafüzérgyöngy, pipa, puskagolyó, elvétve érmék, illetve zarándokjelvény). ${ }^{71}$ Ebból kifolyólag az egyes lelőhelyek pontosabb keltezése csak a történeti és régészeti adatok együttes figyelembevételével, nemegyszer modern kormeghatározási eljárásokkal lehetséges.

Fontos, e lelőhelyek régészeti vetülete miatt sem mellőzhetó szempont a holttestekkel való korabeli bánásmód kérdésköre. ${ }^{72} \mathrm{E}$ tekintetben nem követtek általános szabályokat; ez területenként, régiónként, városonként akár adott időszak alatt is teljesen eltéró lehetett, továbbá nagymértékben függött az elítélt társadalmi helyzetétől, az alkalmazott kivégzési módszerektól és büntetési tételektôl. Egyetemes érvényú jelenségként fogalmazható meg ezekben az esetekben - egyes kivételektől eltekintve - a keresztény rítus szerinti temetkezés megtagadása. ${ }^{73} \mathrm{~A}$ testet elhantolhatták a kivégzés helyszínén (a vesztóhely mellett vagy alatt), ${ }^{74}$ az erre a célra szolgáló elkülönített sírmezőben ${ }^{75}$ vagy egyéb, közösségi temetőkön kívüli területeken (útkereszteződéseknél, út menti kereszteknél, képoszlopoknál, elhagyott épületek romjainál stb.) is. A tetemeket, vagy egyes testrészeket hosszabb-rövidebb ideig közszemlére tehették; végül pedig a kivégzési procedúra részeként (égetés, vízbe fojtás) vagy azt követően megsemmisíthették. A kivégzőhelyeken egyébként a kiközösítés egy formájaként az öngyilkosságot elkövetóket is eltemethették, ${ }^{76}$

71 Busch 2008, 104; LAVI 2008, 109; ReYNOLDS 2009, 140, 177-178; DuMA 2015, 188-192.

72 A kérdésről összefoglalóan: Duma 2010, 83-84. A testek halál utáni változatos sorsáról a büntetések függvényében 14-15. századi itáliai krónikákból és periratokból is értesülünk: DEAN 2007, 62-67.

73 A temetés megtagadásának általános eseteiról, körülményeiről egyházi és történeti források alapján: SzUROMI 2005, 10-11; KUBINYI 2005, 13.

74 DÜLMEN 1990, 150. A szebellébi (Sebechleby, SK) anyakönyv egy 1748-ban kelt bejegyzése szerint a szándékos emberölésért lefejezett "Szúdon lakos Melich Georgius" fejét karóra helyezték, míg "a visszamaradó test az akasztófa/vesztóhely alatt lett eltemetve." (https://familysearch.org/ark:/61903/ 3:1:33SQ-GT99 $C M Q$ ? $m o d e=g \& i=270 \& w c=9 P Q 9 M N T \% 3 A 1$ 07654301\%2C109468701\%2C137809301\%2C137814101\& cc=1554443.) (Letöltés: 2014. október 31.) A forrásadatot és a latin szöveg fordítását Batizi Zoltánnak (Börzsöny Múzeum, Szob) köszönhetem.

75 Feltehetően ilyen - településen belül elkülönített - kivégzettek sírjait is tartalmazó, 15-17. század közé keltezett temetó került elő újabban a lengyelországi Gliwicében (Gleiwitz): ОвтUєоWICZ-PокUTTA 2014, 313-341. A tanulmányra Ritoók Ágnes (Magyar Nemzeti Múzeum) hívta fel a figyelmemet.

76 DülmEN 1990, 124-125; Duma 2015, 227. Az öngyilkosok testét igen gyakran az elítéltekhez hasonlóan kezelték: DuMA 2010, 83. 
valamint ezeket a területeket dögtemetőként, ${ }^{77}$ esetenként szemétégetóként is használhatták. ${ }^{78}$

\section{Szempontok és példák a vesztóhelyek azonosításának lehetôségeihez Magyarországon}

Annak ellenére, hogy teljes körúen feltárt és dokumentált vesztőhely egyelőre nem ismeretes a középkori és 16-18. századi Magyarország területéről, a különféle forráscsoportok adatai alapján számos, a korabeli ítélet-végrehajtással kapcsolatba hozható létesítmény múködése bizonyítható az időszakban, amelyek között nagy számban említhetünk kivégzőhelyeket is. A jogi kultúrtörténet és vesztóhelyrégészet hagyományos európai módszereinek megfelelően ezek azonosítása és lokalizálása az írott forrásanyag (törvényszövegek, periratok, jogi és történeti forráskiadványok, felmérések, összeírások, határjárások és egyéb levéltári dokumentumok), a városképek (metszetek) és a különböző időszakokból, de különösen a 18-19. századból fennmaradt, többnyire már egységes elvek szerint készült részletes térképek alapján lehetséges. Önmagukban ezek a forrástípusok csak korlátozottan alkalmasak a vesztóhelyek lokalizálására vagy a büntetés-végrehajtásban használt objektumok helyének, formáinak és típusainak meghatározására. Együttes értékelésük alapján (kiegészítve a terepbejárások és régészeti kutatások eredményeivel) azonban lehetőség nyílhat e lelóhelyek lokalizálására, egykori területük pontosabb behatárolására, ami lehetőséget nyújthat esetleges feltárásukra is.

Az írásos adatok többnyire csak általánosságban tudósítanak egy-egy vesztóhely puszta létezéséről, felállításának engedélyezéséről, ${ }^{79}$ építé-

77 A hóhér feladatai között említik többek között az elhullott állatok tetemeinek összegyuujitését és elszállítását (DÜLMEN 1990, 84), amely javadalmazásuk tételei között is szerepel (DAVIDOvics 2006, 62). Megjegyzendő, hogy a 14-17. század büntetőjogi gyakorlatában (bizonyos területeken még ennél is korábban) megfigyelhető a háziállatok elítélése, valamint felhasználásuk a büntetés-végrehajtásban és a megszégyenítésben (BódiNé 2014, 36-40). Egyes állattemetkezések régészeti jelenségeinél szisztematikus kivégzést tételezhetünk fel (REYNOLDS 2009, 172).

78 A 19. századi kolerajárvány nyitrai betegeinek ruházatát és ágyszalmáját a hatóságok az "Akasztóhegy alatt" égettették el, NAGY 1876, 34. A forrásadatot Csuthy Andrásnak (Duna Menti Múzeum, Komárom, SK) köszönöm.

79 Mátyás király 1466. január 17-én kelt oklevele megadta a jogot a pálos rendnek, hogy saját birtokaikon ítélkezhessenek, azaz "patibulum, rotas, palos ac aliorum formentum" felállíthassanak. BENCZE-SZEKÉR 1993, 9. séről, ${ }^{80}$ áthelyezéséről, ${ }^{81}$ felújításáról ${ }^{82}$ vagy éppen lerombolásáról. ${ }^{83} \mathrm{~A}$ jogi vonatkozású iratok gyakran konkrét büntetőügyek és azok szankciói ${ }^{84}$ vagy a városok bírói joghatóságának gyakorlása kapcsán említik a kivégzőhelyeket; ezek ugyanis a pallosjognak, vagyis a büntetőintézkedések meghozatalának és gyakorlásának külső szimbólumai is voltak. Építésük megakadályozása egyben a bírói hatóság jogainak - és ilyenformán a városjogoknak - a csorbítását is jelentette. ${ }^{85}$ Egyes források adott esetben topográfiai szempontokból értékelhetó részleteket is tartalmazhatnak. Egy 1390-ben kelt oklevélben a budai Nagyboldogasszony- és Mária Magdolnaplébániák közötti perben leírják a két plébánia közötti határvonalat; ennek során említik meg a városi vesztőhelyet, amely a városfalon kívül, a szentlőrinci pálos kolostorhoz tartó út mellett állt. ${ }^{86}$ Érdekes egybeesés, hogy az ennek közelében, szintén a városfalon kívül települt Szent Lázár-ispotály a feltételezések szerint lepratelep volt. ${ }^{87}$ Ilyen vagy ehhez hasonló, bélpoklosok számára épült - feltehetóen izolált - telepeket máshol is említenek az akasztófák szomszédságában. ${ }^{88}$ Előfordul, hogy a forrás szövege alapján

80 Székesfehérvár városi tanácsa az 1703. évi kiváltságlevélben foglaltaknak megfelelően felállíthatta joghatóságának jelképét, az akasztófát és a pellengért. Az építkezésen nyolc napig dolgozó kőmúveseket és ácsokat első napi munkájuk után a tanács figyelmeztette, hogy "kevesebbet igyanak, és többet dolgozzanak": KÁllaY 1974, 163, 170. Pécs 17-19. századi kivégzőhelyének építéséről és az ott felhasznált építőanyagról vizsgálati jegyzőkönyvek is tanúskodnak: MADAS 1977, 286.

81 A Szépítési Bizottmány tervei alapján a pesti vesztőhelyet 1827 körül távolították el korábbi helyéről, az ún. Parasztpiacról és a mai Baross tértől északra helyezték át: BÁcSKAI 1971, 45.

82 Egy 1747-ben kelt tanúvallomás szerint a pécsi vesztőhelyet 1730 körül felújították, és ekkor a püspök a várostól azt saját hatáskörbe vonta: MADAS 1980, 232.

83 A Kanizsa város tanácsa által komoly anyagi ráfordítással emelt vesztőhelyet egy területi vita miatt 1697 júliusában lerombolták: RÓzSA 2003, 210. Az adatért Várkonyi-Nickel Rékának (MTA Bölcsészettudományi Kutatóközpont Néprajztudományi Intézet) tartozom köszönettel.

84 BÓNIS 1962, 178-179.

85 A budai várban székelő katonai parancsnokság 1694 májusában meggátolta, hogy a bitófa már kifaragott gerendáit kivigyék a városkapun, így Buda még évekig nélkülözte a „vérhatalom" gyakorlásának jelképét. Pesten ugyanakkor már 1693 végén lefejeztek egy férjét meggyilkoló asszonyt (akinek kezét kerékre túzték, testét a vesztőhelyen temették el), fél évre rá pedig az akasztófát is felállithatták. BóNIs 1962, 21-23, 179.

86 A határjárás a mai Margit körút vonalát követte a vesztőhelyig, amely feltehetően a Széna tér környékén állhatott. VÉGH 1997, 301, 29. lábjegyzet; 1999, 331, 344, 3. lábjegyzet.

87 VÉGH 2006, 132. Ugyanitt lásd az 1390-es határjárás vonatkozó szövegrészletét is. Az oklevél kivonata: VÉGH 2008, 42. 88 SOKOL 2003, 745. 


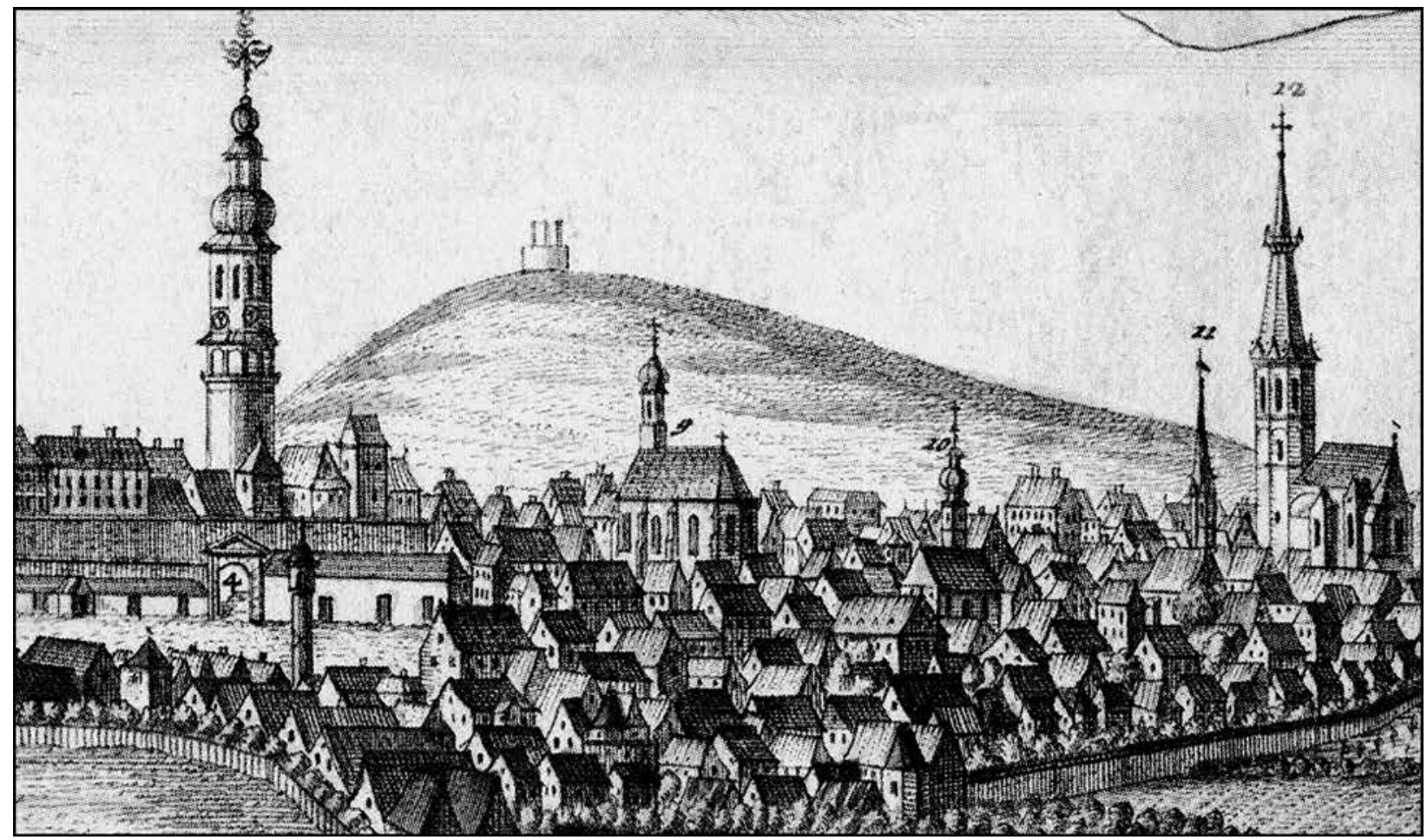

6. kép. Vesztőhely ábrázolása Sopron 1730 körüli látképén (MVA 1 2010, C.4.2. tábla nyomán)

Fig. 6. Depiction of an execution site on a view of Sopron, ca. 1730 (after MVA 1 2010, Pl. C.4.2)

az építmény külső kinézetére is következtethetünk. A 18. század elején múködő, ismeretlen fekvésú egri ítéletvégrehajtó hely kiemelt, nyitott ponton vagy magaslaton állhatott, és lépcsóvel is rendelkezhetett; egy 1703-ban lezajlott incidens alapján legalábbis erre gondolhatunk. ${ }^{89}$ Egyes kimutatások, jegyzőkönyvek „beszédes” földrajzi nevei is vesztóhelyeket takarnak; ilyennek tekinthető a miskolci Újváros szélén a 18. században keletkezett településrész, ahol több utca is a terület korábbi funkciójára utaló 'Nyakvágó' nevet viselte, ${ }^{90}$ vagy az Óbuda akkori határán emelkedő, az egykori római katonai amfiteátrum területén fekvó 'Schintersberg', ez esetben a kivégzőhely meglétét több más adat is igazolja. ${ }^{91}$

A képi források között elsősorban a városképeket, metszeteket, vedutákat, illetve az egyes képzómúvészeti alkotásokat említhetjük meg. Az előbbieken nagy számban találunk vesztőhelyeket, illetve bitófákat, ezek hitelessége azonban az esetek egy részében megkérdőjelezhető; gyakori ugyanis, hogy a kivégzőhelyeket jelképes ábrázolásként vagy a büntetô hatalom szimbólumaként tüntetik fel, a készítő által olyan jellegze-

89 Amikor az elítéltet a hóhér a lépcsőn fel akarta vezetni, két nő a fejére kendőt dobva megpróbálta kiszabadítani. NEMES 2001, 81.

90 GYUlai 1999, 180; 2000, 105.

91 JANKOVICH 1963, 157. tesnek gondolt elemként, amely a valóságban egyáltalán nem vagy nem ott létezett. ${ }^{92}$ A városok környékének kiemelkedő pontjaira épített akasztófák és azok környezete hadmúveletek esetén olykor stratégiai jelentőségúnek számított, többnyire tüzérségi ütegállásként vagy erődítmény, esetleg sánc részeként; ezzel is magyarázható, hogy az ostromábrázolásokon rendszeres a megjelenítésük..$^{93} \mathrm{~A}$ magyarországi városképek ilyen irányú értékelése még nem történt meg; vizsgálatuk egyes települések esetében azonban nem csak a vesztőhelyek egykori elhelyezkedésére ${ }^{94}$ hanem azok formájára nézve ${ }^{95}$ is szolgáltathat támpontokat (6. kép).

92 Német területeken több mint kétezer 16-17. századi metszet vizsgálata alapján 206 vesztőhelyet azonosítottak. EvERS $2008,447$.

93 SOKOL 2008a, 496-505.

94 A Nicolo Angielini által 1566-ban Győrről készült látképen a Rába bal partján feltüntetett akasztófa valószínúleg tévedés (esetleg jelképes ábrázolás), hiszen a vesztőhely a Rábától keletre eső dombon volt, amelyet szintén jelöl az akvarell, és funkcióját - Berg des Gerichts - is megnevezi. SZÉKELY 2004, 170; 2006, 142.

95 Sopron egyes 18. századi látképein a várost körülvevő dombok közül a jobb oldalin tüntetik fel a vesztőhelyet, amely jól kivehetően falazott - talán négyzetes - alapozással és háromágú bitófával rendelkezett: RózSA 1996, 202-204, 1-3. kép. A város kivégzőhelye a Bécsi-dombon (Wiener Berg) állt, 1595ben Hochgericht, a későbbiekben Galgenberg, am Gericht, Gerichtshügel neveken említik. 1836-ban és 1843-ban 
Noha egészen más céllal készültek, egyes képzőmúvészeti alkotásokon - festményeken, tájképeken, életképeken - gyakran olyan részletesen és realista módon ábrázolják a korabeli büntetésvégrehajtás módszereit, eszközeit és objektumait, hogy azok történeti szempontból is értelmezhetőek. ${ }^{96}$ Külön kategóriát jelentenek a bíróságot, büntetőeljárást, egyes búncselekményeket és büntetéseket is ábrázoló miniatúrák és táblaképek. ${ }^{97} \mathrm{Az} 1497$ előtt keletkezett Hamburger Stadtrecht táblaképén felfedezhető a törvényszolga háza (amely börtönként is funkcionált), a hamburgi pellengér és szégyenketrec, a háttérben pedig a hóhér alakja, valamint a vesztőhely a kétoszlopos bitóval és az oszlopokra helyezett kerekekkel (7. kép). ${ }^{98}$

A harmadik forráscsoportot a régészeti lelóhelyek azonosítása, illetve a településtörténeti vizsgálatok szempontjából meghatározó jelentőségú történeti térképek jelentik. Közöttük is kiemelkedő fontosságúak az 1763-1887 között a Magyar Királyság teljes területéról készült katonai felmérések, valamint a 18-19. század kataszteri felmérései. Ezek - a korábbi idószakok pontatlan, sokszor kezdetleges térképeihez képest - mind méretarányukat, mind a természetes vagy mesterséges tereptárgyak ábrázolását és felirataikat, jelkulcsaikat tekintve is elsődleges információhordozóknak tekinthetők. A térképszelvények ábrázolásai és szöveges magyarázatai között nagy számban találhatók a korabeli büntetésvégrehajtás objektumaira, különösen a vesztőhelyekre utaló jelzések. Jelentősebb útelágazásoknál, települések közelében, jellemzően magaslati pontokon az akasztófa megjelenítése mellett szöveges magyarázatként a "Vesztóhely", "Gericht", „Hochgericht”, ,Berggericht”, "Galgen”, "Galgenberg" szerepel a leggyakrabban. A dúlőnevek között az „Akasztó-hát”, „Akasztó-domb” stb. elnevezések is jelölhetnek ilyen területeket. ${ }^{99}$ A jelkulccsal ábrázolt bitófák formái szintén árulkodók lehetnek: így például Nagykanizsától keletre négyágú, Kaposvártól északnyugatra három- és négyágú, Székesfehérvár északi és déli részén egyaránt kétágú, Szentestől keletre há-

Vesztôhely, 1847-ben Vesztôfa néven ismert. 1853-ban végleg eltávolították: CsATKAI 1937, 38. MVA 1, 2010, 78.

96 Hieronymus Bosch (1450-1516), idősebb Pieter Brueghel (1525-1569) és Jacques Callott (1592-1637) múvei a legismertebbek: BusCH 2010, 296-299, 301-302.

97 BusCH 2010, 298-299.

98 MeZey 2010, 73.

99 CSENDES 1977, 247. A kunhalmok között is találunk „Akasztóhalom” vagy "Akasztó-hegy" elnevezésúeket, amelyek területén egykor szintén vesztőhelyek lehettek; ilyen gyanítható például a Jászapáti határában fekvő halom esetében is. ТóтH 1989, 429.

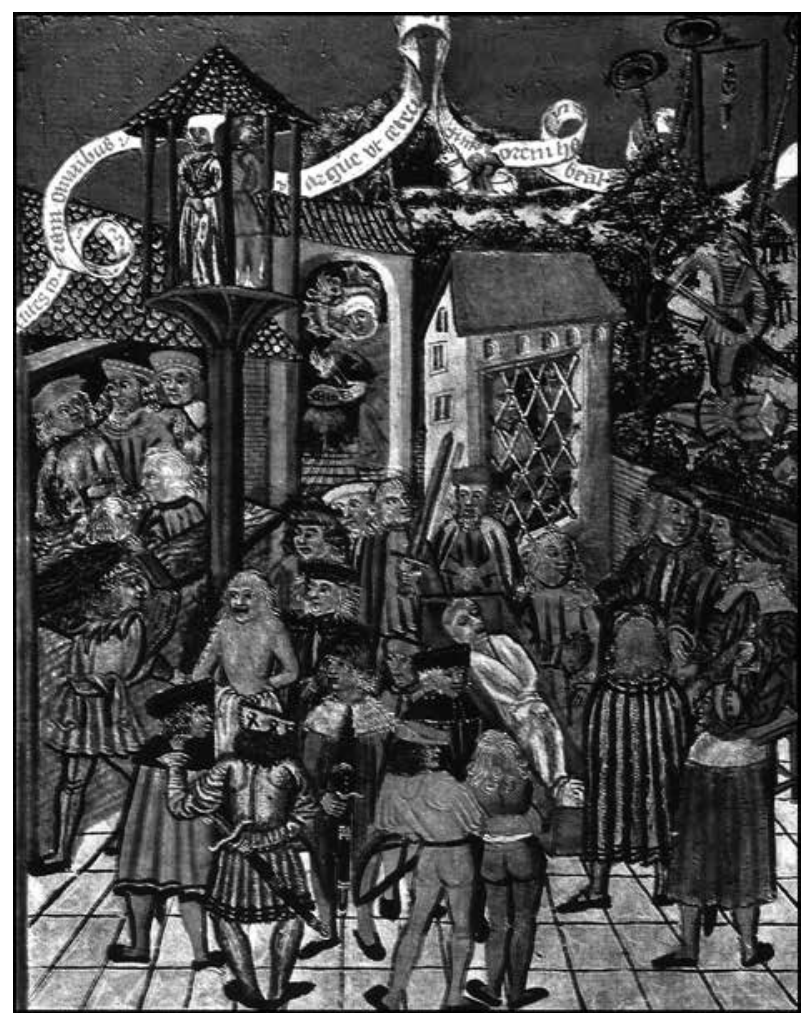

7. kép. Börtön, pellengér és vesztőhely ábrázolása a Hamburger Stadtrecht 1497 előtti táblaképén (Mezey 2010, 73 nyomán)

Fig. 7. Depiction of a jail, a pillory and an execution site on a pre-1497 illustration to Hamburger Stadtrecht (after MEZEY 2010, 73)

romágú akasztófák tưnnek fel az első katonai felmérés térképein. ${ }^{100}$ Általános szabályként érvényesült a felmérések készítésekor, hogy a kóből emelt objektumok piros, az egyéb anyagból (fából) épültek fekete színúek. ${ }^{101}$ Ennek megfelelően a térképek elemzésekor a vesztőhelyek építóanyagát tekintve is fontos információkat nyerhetünk, amelyeknek adott esetben régészeti szempontból lehet jelentősége.

Egyes térképeken az egyszerú akasztófáknál lényegesen nagyobb, azoknál jóval összetettebb struktúrájú ítélet-végrehajtó helyeket is felfedezhetünk. Lapos tetejú, négyszögletes, kőból emelt, egyik oldalán boltíves kialakítású ajtóval záródó, négyoszlopos bitóval ellátott építményt ábrázol a Pécs városáról 1815-ben készült ún. Quits-féle térkép egyik táblája 'Das Hoche Gericht' jelöléssel. A tömeges kivégzésekre is alkalmas, ma már beépített területen fekvő, a 17. század végén épített vesztőhely létét és használatát több más forrás is alátámasztja. ${ }^{102}$

\footnotetext{
100 CSENDES 1977, 261-264.

101 JANKÓ 2001, 114.

102 MADAs 1977, 285-286.
} 


\section{Büntetés-végrehajtással kapcsolatos jelenségekre vonatkozó magyarországi régészeti adatok}

Magyarországon a korabeli igazságszolgáltatással kapcsolatba hozható régészeti jelenségeknek, objektumoknak és leleteknek csak szórványos nyomaival találkozunk. Ennek egyik oka azok egykori fekvéséből is következik; a településektôl távolabb kialakított, kis kiterjedésû, szegényes leletanyagú lelőhelyek rendszerint kívül esnek az ásatások többnyire lakóhelyekre és azok környezetére koncentráló területén. A városok belterületén folyó feltárások esetében az ilyen jellegú, zömmel a kora újkorra-újkorra keltezhetó jelenségek nagyobb, gyakran több régészeti korszakot is átfogó, az idók folyamán sokszorosan bolygatott, többször beépült területek ásatásai során bukkannak fel, és mind mennyiségüket, mind jellegüket tekintve másodlagos jelentőségúek. További problémát jelent, hogy az idesorolható, egyéb forrásokból amúgy jól ismert emlékek egy része régészetileg kimutathatatlan, vagy csak nagyon nehezen kimutatható (például a fából ácsolt ideiglenes jellegú vérpadok vagy az egyszerú szerkezetú bitófák cölöpgödrei). Nem kizárt ugyanakkor az sem, hogy az esetleg kivégzóhelyként is azonosítható magaslatok, halmok régészeti megfigyelés nélkül történt földmunkáinál korábban akár idetartozó jelenségek is előkerülhettek; ezekról értelemszerúen nem vagy alig rendelkezünk információkkal. ${ }^{103}$ Végezetül számos esetben csak feltételesen sorolhatók bizonyos atipikus régészeti jelenségek - különösen a rendellenes helyzetú temetkezések - ehhez a körhöz; értelmezésükben a kivégzésen kívül több más lehetőség is elképzelhető. ${ }^{104}$ Ennek ellenére - a fentebb már említett, a jakobinusokhoz köthetô sírokon kívül - a magyarországi régészeti kutatások során is több esetben kerültek elő egykori büntetés-végrehajtással kapcsolatos lelóhelyek.

$\mathrm{Az}$ aquincumi katonai amfiteátrumban 19381942 között folytatott kutatások során a középkorban beépítetlenül maradt arena területén a vékony törmelékrétegbe ásva két sérült emberi csontvázat, valamint külön egy vasból készült kéz- és lábbilincset találtak. ${ }^{105}$ Ezeket már ekkor a 18. században itt múködő, a század közepén

\footnotetext{
103 Egy példa a fentebb már említett Akasztó-hegy Jászapáti mellett, ahol az 1976-os, majd az azt követő halomroncsolás során több - közelebbről nem meghatározott - régészeti lelet is előkerült. TóTH 1989, 429.

104 GARDELA-KAJKOWSKI 2013, 780-796.

105 NAGY 1943, 374.
}

máshonnan áthelyezett ${ }^{106}$ vesztóhellyel hozták összefüggésbe.

Váctól délre, a Duna és a budapesti országút közötti homokterasz, a mai Derecske-dülő területéról a 20. század eleje óta ismertek különböző korszakok leletei. A lelóhely déli részén volt az Akasztó-hegy, a róla elnevezett Akasztófa-dúlő homokbányájában 1952-ben 6-7 csontvázas sír került elő. Ezt követően Patay Pál háromnapos leletmentéssel 10 sírt tárt fel, amelyek közül 5 biztosan kora Árpád-kori, a többi a közelebbről nem keltezett újkorban itt lévő vesztőhelyhez tartozhatott. 107

Visegrád-Várkert lelőhelyen az itt feltárt kora Árpád-kori település területéről az 1980-ban Kovalovszki Júlia vezetésével végzett ásatás során a templom körüli temetőn kívül egy nagyméretú, $130 \mathrm{~cm}$ átmérőjú igen mély verem alján részleges emberi csontváz, valamint felette és mellette 6 kutya csontmaradványai bukkantak elő (8. kép). ${ }^{108} \mathrm{Az}$ emberi csontok egy felnőtt (maturus korú) nő jobb oldali összefüggó vázrészeinek (medence-comb-lábszár-lábfej) bizonyultak; elókerültek a koponya, az állkapocs, a jobb oldali lapocka és egyes bordák töredékei is. A kutyavázak közül három szinte teljes anatómiai rendben a verem északnyugati, legalább további három egyed csontjai pedig szétszóródva a verem déli felében feküdtek. Az elsődleges vizsgálatok az emberi és állati csontok egy részén vágásnyomokat állapítottak meg; ennek alapján a 10-11. századra keltezett ${ }^{109}$ leletegyüttest a felnégyelés mint középkori kivégzési mód egyedülálló régészeti bizonyítékának, a kutyákkal való eltemetést pedig a halálban történt kiközösítés, megalázás egy formájának tekintik. ${ }^{110} \mathrm{Az}$ emberi és állati csontmaradványok újabb, jelenleg is

106 Az 1702. évi összeírás szerint Buda város akasztófája ekkor a mai Szépvölgyi út környékén, egy ebben az időben beépítetlen térségen állhatott. Ezt helyezték át 1735 táján Óbuda határára, a római amfiteátrum maradványait rejtő magaslatra, amely a Königsberg, Schintersberg, Galgenberg neveket viselte. JANKOVICH 1963, 157. Ismert Hundsberg névváltozat is. PÓCZY 1994, 27-28.

107 MRT 9, 1993, 471-472. A lelőhelyre Batizi Zoltán (Börzsöny Múzeum, Szob) hívta fel a figyelmemet, segítségét köszönöm.

108 KovalovszKi 1980a.

109 A verem betöltésének felső egy méterében, kissé hamusfaszenes betöltésben kevés kora Árpád-korinak meghatározott kerámiatöredék, egy kis vaskés és néhány állatcsont került elő. KovALOVsZKI 1980b, 10. Mivel a keltező leletanyag szinte teljesen hiányzik, és lehetőségként felmerült, hogy a maradványok az Árpád-kornál későbbi időszakból származnak, szükséges a maradványok radiokarbon-vizsgálata is, ami a közeljövőben megtörténik.

110 VÖRÖS 1991, 185-188. 


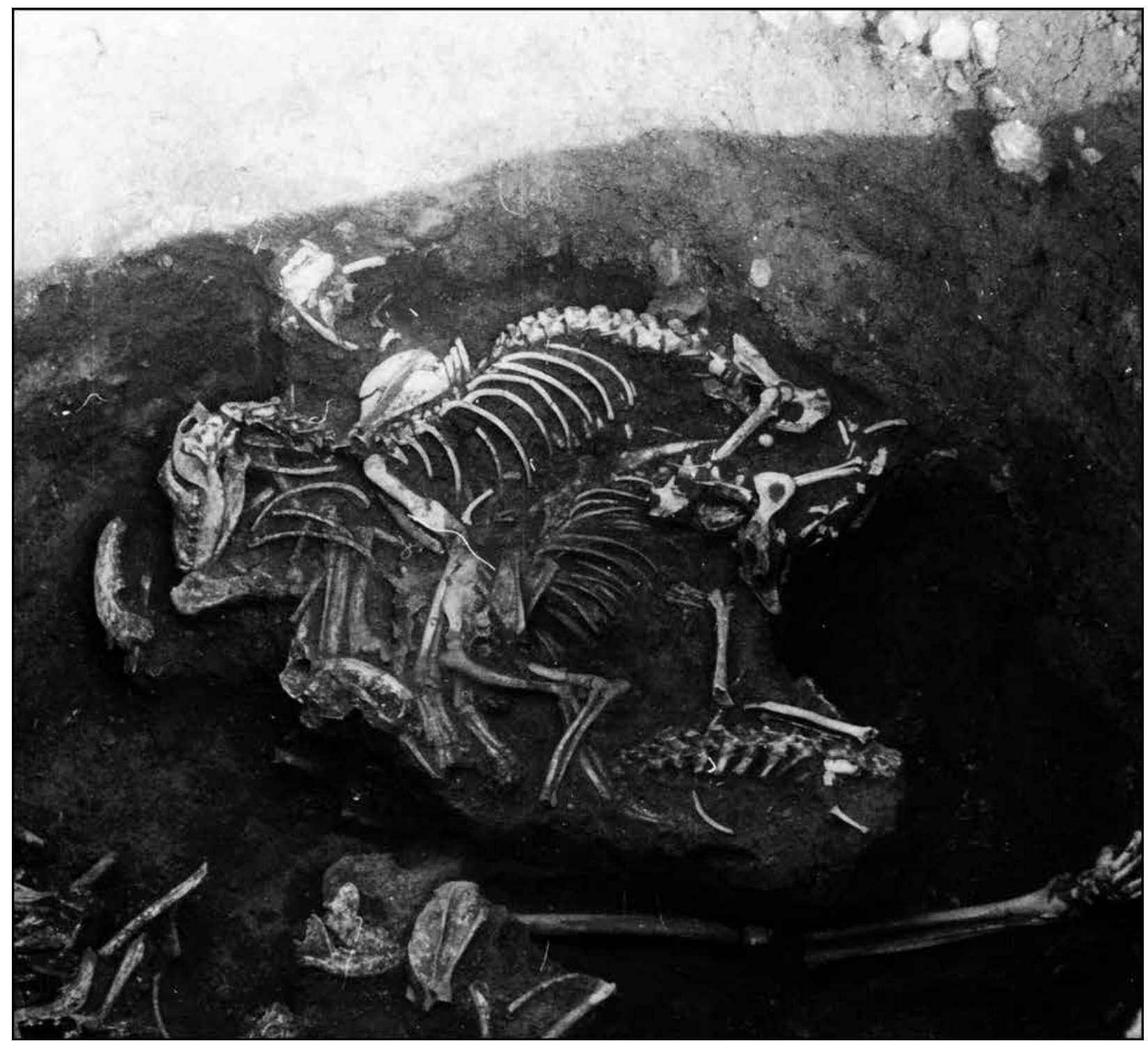

8. kép. Kutyákkal eltemetett emberi maradványok Visegrád-Várkert lelőhelyen (KovALOvSZKI 1980b, XIX. tábla, 2. kép nyomán)

Fig. 8. Human remains buried with dogs at Visegrád-Várkert (after KovALOVSZKI 1980b, Pl. XIX. 2)

folyó természettudományos vizsgálatai ${ }^{111}$ azonban a felnégyelés tényét nem támasztják alá. A nói csontvázon és a kutyavázakon vágások egyértelmú nyomait nem lehetett felfedezni, azonban nem teljesen kizárt, hogy ezeket a post mortem vagy tafonómiai folyamatok miatt nehezebb felismerni. A tetem nagy részének hiányát, megsemmisülését okozhatta ragadozók (kutyák) általi roncsolás is, az erre utaló rágásnyomok

$111 \mathrm{Az}$ antropológiai vizsgálatokat László Orsolya (Magyar Nemzeti Múzeum, Alkalmazott Természettudományi Laboratórium), az archaeozoológiai kutatást Bárány Annamária (Magyar Nemzeti Múzeum, Régészeti Tár) végzi, munkájukat és segítségüket hálásan köszönöm. nyilvánvalóak a csontokon. A megfigyelések azt valószínúsítik, hogy a koponya a testtól elválasztva kerülhetett a verembe, továbbá egyes csontokon ütéstól is származtatható sérülések vannak; ezek alapján elképzelhető az - akár kivégzés során bekövetkezett - erőszakos halál. ${ }^{112}$ A Visegrád-Várkertben fekvő falu területéről a fentieken kívül is bukkantak elő a feltételezések szintjén büntetés-végrehajtással kapcsolat-

112 László Orsolya és Bárány Annamária szíves közlése. A még folyamatban levő vizsgálatokról azok lezárultával önálló publikációban szeretnénk beszámolni. 


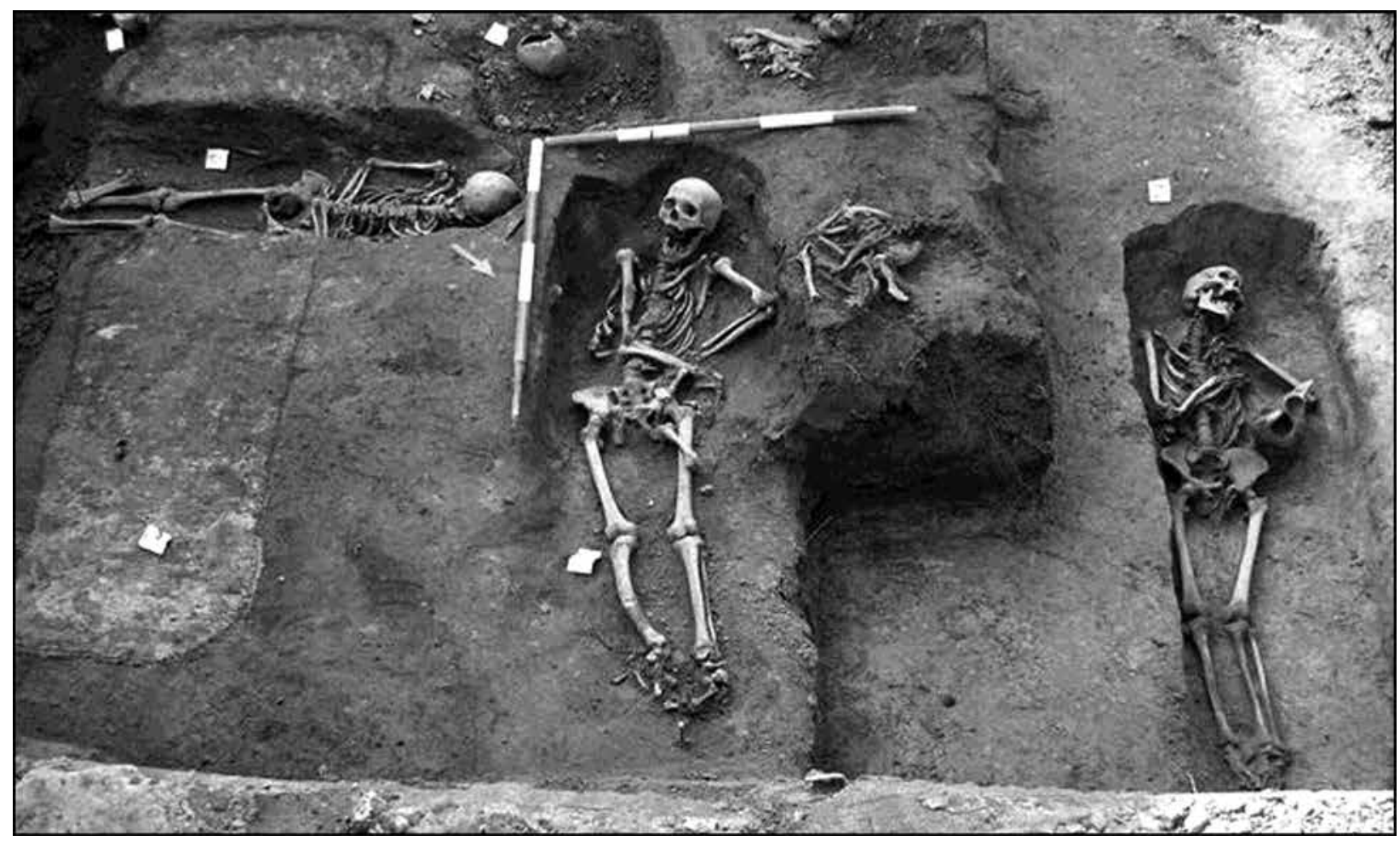

9. kép. Rendellenes helyzetú 18. századi temetkezések Vác-Zichy utca 20. lelőhelyen (Batizi Zoltán felvétele, a szerző engedélyével)

Fig. 9. 18th-century deviant burials at 20 Zichy Street in Vác (photo courtesy of Zoltán Batizi)

ba hozható jelenségek, amelyek további tisztázásra várnak. ${ }^{113}$

Vácon, a Zichy utca 20. számú telken az egykori német város városfala mellett és a falon kívüli részen 2005 októberében a Batizi Zoltán által vezetett megelőző feltárás során megtalálták a középkori fal legalsó részének kötésben levő darabjait; e fal nagyobb részét egy 18-19. században ásott árokkal pusztították el. A falon kívül két további, azzal párhuzamos, V keresztmetszetú, betöltésük anyaga alapján 18. századi árok húzódott. A külsó árok vonala mellett, annak közvetlen közelében hat szabálytalan helyzetú, a szegényes kerámiaanyag alapján a 18. századra keltezett temetkezés került elő (9. kép), amelyek közül az egyik kettős sírnak bizonyult (10. kép). Négy sírgödör iránya északkelet-délnyugati volt, az ötö-

113 2000-ben szondázó jellegú kutatás során két rendellenes helyzetú sírt tártak fel a települést határoló vízmosás keleti oldalán, amelyek közül az egyiket III. Béla-éremmel datált rétegbe ásták. A kevert, kevés ôskori és Árpád-kori leletanyagot is tartalmazó betöltésben nagy mennyiségú állatcsont és freskótöredék is volt. A csontvázak mellett elókerült egy 50-60 cm átmérőjú habarcsfolt is, amely talán valamilyen építmény, esetleg oszlop vagy gerenda megerősítésére szolgálhatott. Gróf Péter (MNM Mátyás Király Múzeum) szíves szóbeli közlése, továbbá GRÓF 2003, 232-233. dik rájuk merólegesen helyezkedett el. A csontvázak oldalra fektetve, felhúzott lábakkal vagy háton, nyújtott testhelyzetben, de véletlenszerú kartartással feküdtek. A kettős sír egyik halottjának koponyáját az oldalra fektetett testtel ellenkezó irányba nézve találták. A sírokban, illetve azok mellett állatmaradványok (kutya?) is napvilágot láttak. Mivel a közelben templomnak, temetőnek nincs nyoma, az ásató feltételezése szerint az egykori városárok mellé a koporsó és minden ruhatartozék vagy egyéb melléklet nélkül elhantolt személyek feltehetóen törvényen vagy társadalmon kívüliek, esetleg kivégzettek lehettek. ${ }^{114}$ Ezt megerősíteni látszik, hogy a "tisztességtelen temetés" Európa-szerte ismert gyakorlata során a települések perifériáján vagy a vesztőhelyek környékén gyakran ún. „hamis temetők” (Faulx âtre) alakultak ki, ahová a kivégzések áldozatait, az öngyilkosokat vagy olyan személyeket temettek, akiktől különböző okokból megtagadták a végtisztességet. ${ }^{115}$

114 BATIZI 2005; 2006, 332. Itt szeretném megköszönni Batizi Zoltánnak, hogy az ásatás eredményeinek publikálását átengedte, valamint nélkülözhetetlen segítségét a témával kapcsolatos adatgyújtésben.

115 DUMA 2010, 84. 


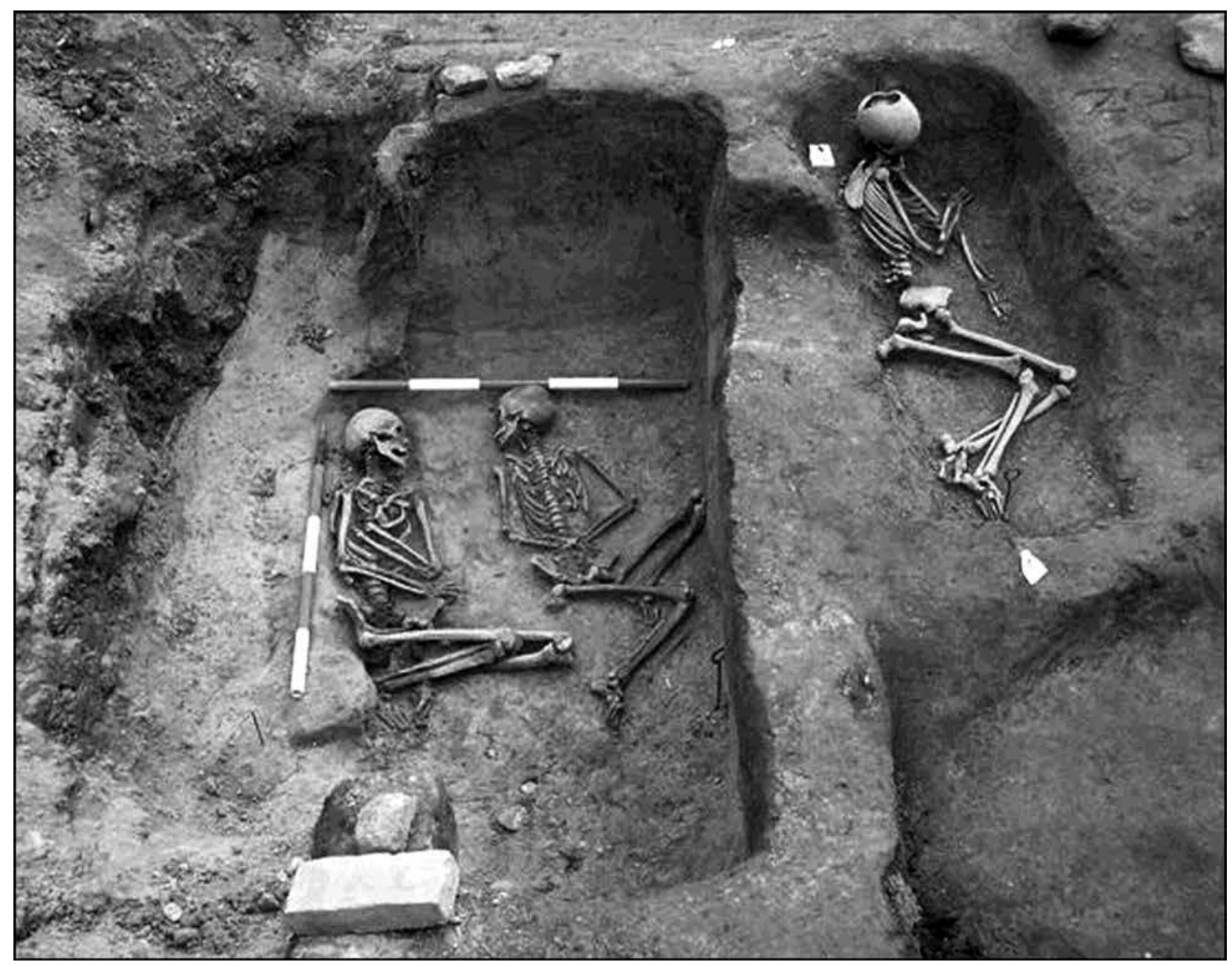

10. kép. Oldalra fektetett, zsugorított helyzetú, 18. századi temetkezések Vác-Zichy utca 20. lelőhelyen (Batizi Zoltán felvétele, a szerző engedélyével)

Fig. 10. 18th-century crouched burials at 20 Zichy Street in Vác (photo courtesy of Zoltán Batizi)

A büntetés-végrehajtás objektumai közül újabban szégyenoszlopok, pellengérek maradványait is ismerjük, amelyek jellemzően a városok központi, gyakran a középkor óta beépítetlen vagy csak részben beépített területein folyó régészeti kutatások során bukkantak elő. A győri Széchenyi téren 2008-2009 folyamán több korszak emlékei mellett két pellengér nyomait is azonosították. Az elsőt valószínúleg a 18. század első harmadában emelték a téren álló Mária-oszlop és a későbbi Lloyd-épület (korábban katonai várta) közé, talán a várfal visszabontott tégláiból. A nagyjából 2,2×2,2 méter nagyságú tömb közepén jól kivehetóen megmaradt az egykori szégyenoszlop helye is (11. kép). Nem sokkal késóbb, a 18. század közepén a Mária-oszlop másik oldalán újabb, téglákból emelt négyzetes pellengért alakítottak ki, amelynek alapozását figyelték meg; a szégyenoszlop építésének datálását az egyes téglákon megfigyelt 1748-1749-es évszám is segítette.
A tér déli oldalán ekkor múködő jezsuita rendház feljegyzései megemlítik, hogy a pellengért egy évvel felállítása után, 1751-ben a jezsuiták követelésére ledöntötték, majd a külvárosba vitték. Az áthelyezés tényét és dátumát egy 1757-es keltezésú, a Mária-oszlop környezetét ábrázoló metszet felirata is megerösíti. ${ }^{116}$

Pápán, a Fő téren a 2013-ban folyó, nagy felületú megelőző feltárás elsősorban Ârpád-kori, késő középkori és kora újkori objektumokat és leletanyagot hozott a felszínre. A tér 18. századi átépítése során annak keleti sarkában két négyzetes téglaalapból álló építményt emeltek, amely a város pellengéreként funkcionált (12. kép). Az igen igényes, precíz falazású, közvetlenül a jelen-

116 BíRÓ et al. 2010, 45-46. Köszönet illeti Bíró Szilviát (Iseum Savariense Régészeti Múhely és Tárház, Szombathely) a pellengérekre vonatkozó szóbeli és írásbeli információkért, valamint a rendelkezésemre bocsátott képanyagért. 


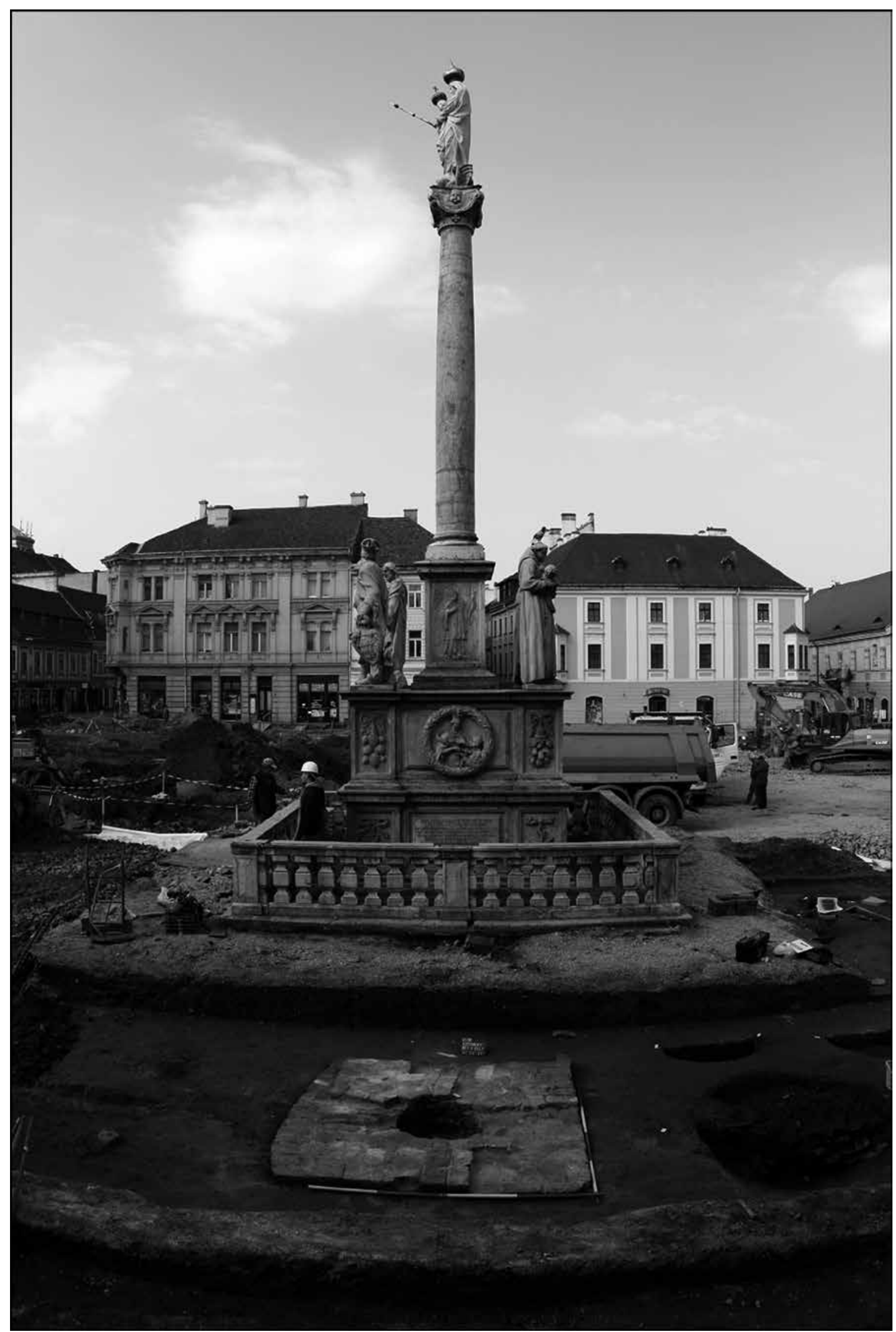

11. kép. Pellengéroszlop alapozásának feltárása a győri Széchenyi téren (Bíró Szilvia felvétele, a szerző engedélyével) Fig. 11. Excavation of the foundation of a pillory on Széchenyi Square in Győr (photo courtesy of Szilvia Bíró) 


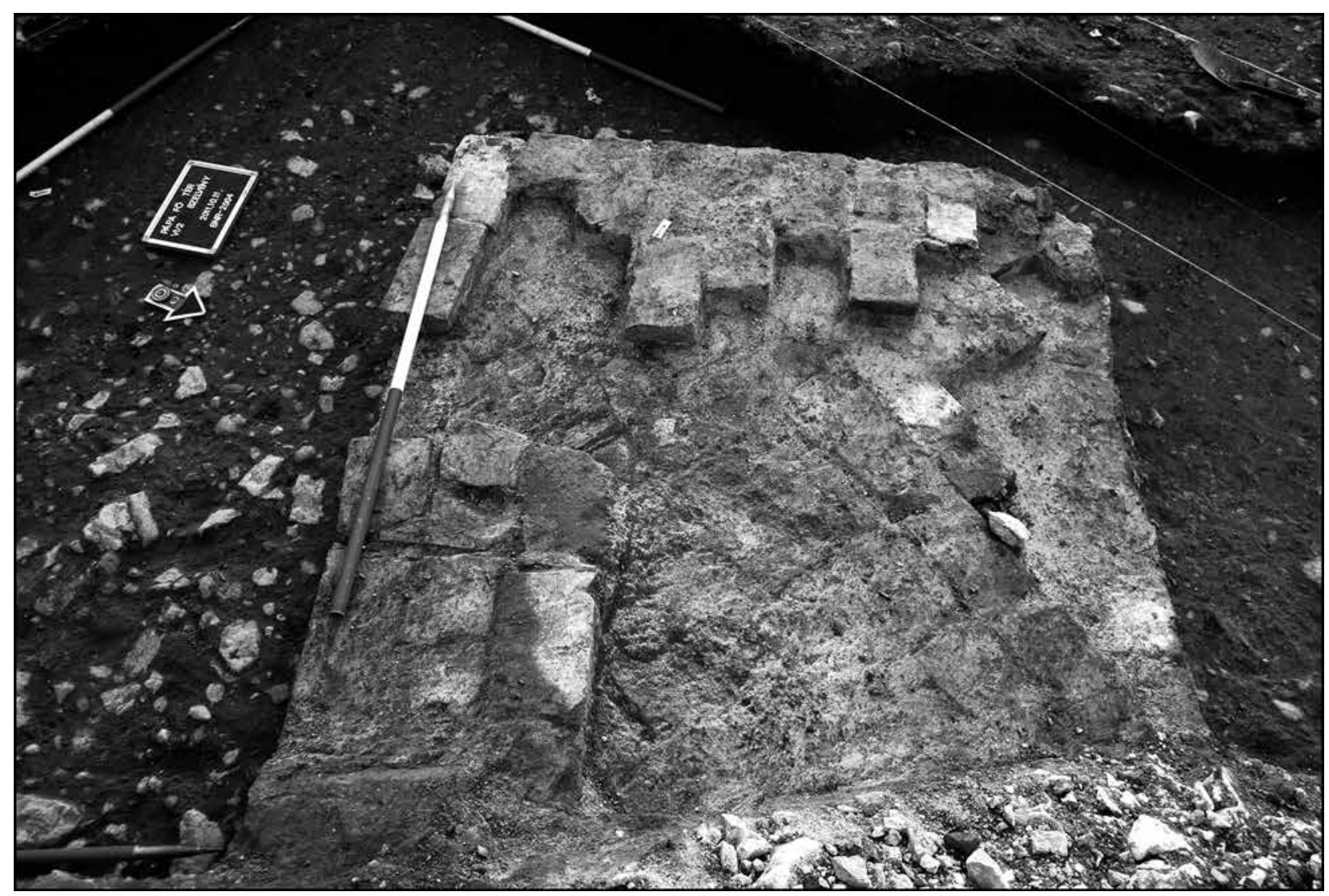

12. kép. Pellengér téglaalapozásának részlete a pápai Fő téren (Mordovin Maxim felvétele, a szerzó engedélyével)

Fig. 12. Detail of the brick foundation of a pillory on Fő Square in Pápa (photo courtesy of Maxim Mordovin)

legi útfelszín alatt jelentkező délnyugat-északkeleti tájolású emelvény körül minden oldalon megtalálták a piactér barokk kori térburkolatát is. Az építkezés keltezését az 1751-es évszámmal ellátott téglák pontosították. ${ }^{117}$

A vesztóhelyeket a 18. század közepétől a nyilvános halálbüntetések visszaszorítását is célzó igazságügyi reformok hatására fokozatosan megszüntették és felszámolták. Csehország, Morvaország és Szilézia területén a 16-18. század között múködő, pallosjogát gyakorló 388 városi tanács csaknem mindegyike rendelkezett kivégzóhellyel, némelyik többel is. A 18. század második felétól a reformok hatására a halálbüntetés kiszabására jogosult hatóságok száma radikálisan 29-re csökkent, míg a 18-19. század fordulójára csak 19 maradt. ${ }^{118}$ Mindez az ítélet-végrehajtó helyek többségének felhagyását és lebontását eredményezte.

\footnotetext{
117 MoRDOVIN 2016, 251. Köszönöm Mordovin Maxim ásatásvezető régésznek (ELTE BTK Régészettudományi Intézet, Magyar Középkori és Kora Újkori Régészeti Tanszék), hogy a pellengér dokumentációját és fotóit a rendelkezésemre bocsátotta, és hozzájárult közlésükhöz.

118 SOKOL 2008b, 250.
}

Magyarországon a fentiekhez hasonló hosszú folyamatok játszódtak le. Az úriszékek pallosjogát már II. József megvonta, de csak 1848-ban szüntették meg véglegesen. A 19. század első felében a nyilvános testi és halálbüntetések helyett egyre inkább a szabadságvesztés vált a fő büntetési formává. ${ }^{119}$ Ebben az időszakban a vesztőhelyek látványa az elrettentés helyett egyre inkább felháborodást váltott ki; ezt fejezi ki az ismert színésznő, Déryné naplóbejegyzése is az egri akasztófáról: „... midőn közel értünk már a városhoz [...] ott pillantottam meg [...] a borzasztó végzetes négy oszlopot, melyen már két hét óta függött négy, a törvény által elítélt gonosztevő. E látvány én bennem [...] borzadást okozott..."120 Minden bizonnyal a közvéleményben is egyre inkább eluralkodó, felháborodással vegyes szánalom is hozzájárult ahhoz, hogy a városok határában hosszú ideje álló vesztóhelyeket az 1850-es években végleg lebontották.

\footnotetext{
119 То́тн J. 2010, 232-246.

120 Idézi Pandula 1989, 12.
} 


\section{IRODALOM}

AULER, JOST

2008a Ausgewählte Altgrabungen mit Richstättenbefunden aus Deutschland. Auler, J. (Hrsg.): Richstättenarchäologie. Dormagen, 12-45.

2008b Richstättenarchäologie in der Schweiz - Einige Nachträge. Auler, J. (Hrsg.): Richstättenarchäologie. Dormagen, 286-307.

2008c Vor der Toren der Stadt - Die südliche Richstätte der rheinischen Stadt Neuss. Auler, J. (Hrsg.): Richstättenarchäologie. Dormagen, 76-81.

2010 Ausgewählte Altgrabungen mit Richstättenbefunden aus Deutschland. (2.) Auler, J. (Hrsg.): Richstättenarchäologie 2. Dormagen, 12-28.

2012 Ausgewählte Altgrabungen mit Richstättenbefunden aus Deutschland. (3.) Auler, J. (Hrsg.): Richstättenarchäologie 3. Dormagen, 24-35.

2013 The Archaeology of Execution Sites in Early Modern Central Europe. Mehler, N. (ed.): Historical Archaeology in Central Europe. Special Publication, Number 10. Society for Historical Archaeology, Rockville, 139-149.

BALOGH ÁRPÁD

2016 Kora újkori vesztőhelyek régészete. Vas vármegye vesztőhelyeinek történeti és térinformatikai vizsgáBALTL, HERMANN lata. Alapszakos szakdolgozat. Eötvös Lóránd Tudományegyetem Bölcsészettudományi Kar.

1957 Rechtsarchäologie des Landes Steiermark. Graz-Köln.

BARTUCZ LAJOS

1966 A magyar jakobinusok sírjainak megtalálása és kétszeri exhumálásuk. Bartucz Lajos: Palaeopathologia

BATIZI ZOLTÁN

III. A praehistorikus trepanáció és orvostörténeti vonatkozású sírleletek. Budapest, 445-519.

2005 Vác, Zichy utca 20. Jelentés megelőző feltárásról. Jelentés és dokumentáció. Kézirat.

2006 Vác, Zichy utca 20. Kisfaludi J. (szerk.): Régészeti kutatások Magyarországon 2005 (Archaeological investigations in Hungary 2005). Budapest, 332.

BÁCSKAI VERA (szerk.)

1971 Források Buda, Pest és Óbuda történetéhez 1686-1873. Források Budapest múltjából I. Budapest Főváros Levéltára Forráskiadványai I. Budapest.

BEHRINGER, WOLFGANG

2010 A klíma kultúrtörténete. A jégkorszaktól a globális felmelegedésig. Budapest.

BENCZE ZOLTÁN-SZEKÉR GYÖRGY

1993 A budaszentlőrinci pálos kolostor. Monumenta Historica Budapestiensia (Budapest) 8.

BENDA JUDIT

2011 A kereskedelem topográfiája. A kereskedők térhasználata a késő középkori Budán. Korall (Budapest) 45, 80-101.

Bíró SZILVIA-MolnÁr AtTILA-SZŐNYI EsZTER-TOMKA PÉTER

2010 Régészeti kutatások a győri Széchenyi téren (2008-2009). Kisfaludi J. (szerk.): Régészeti kutatások Magyarországon 2009 (Archaeological investigations in Hungary 2009). Budapest, 232-233.

BOSCHLER, SUSI ULRICH-LANZ, CHRISTIAN

2008 Mittelalterliche und neuzeitlicheSkelettfunde Hingerichteter in der Schweiz. Katalog und antropologischrechtsmedizinische Beurteilung. Auler, J. (Hrsg.): Richstättenarchäologie. Dormagen, 412-436.

BÓDinÉ BELIZNAI KingA

2013 Kivégzési rituálék. In: Máthé G.-Révész T. M.-Gosztonyi G. (szerk.): Jogtörténeti parerga. Ünnepi tanulmányok Mezey Barna 60. születésnapja tiszteletére. Budapest, 31-45.

2014 A bíbor méltóság, a sárga árulás. Szimbólumok és rituálék a jogtörténetben. Budapest.

BÓNIS GYÖRGY

1962 Buda és Pest bírósági gyakorlata a török kiűzése után 1686-1708. Budapest Várostörténeti Monográfiái (Budapest) 23.

BUSCH, RALF

2008 Das spätmittelalterliche Hinrichtungstätte in Salzhausen, Landkreis Harburg, im archäologischen Befund. Auler, J. (Hrsg.): Richstättenarchäologie. Dormagen, 98-104.

2010 Bilder des Grauens. Hinrichtungstätten in der Kunst. Auler, J. (Hrsg.): Richstättenarchäologie 2 Dormagen, 296-304.

CSATKAI ENDRE

1937 A soproni utcanevek történetéhez. Soproni Szemle (Sopron) 1:1, 37-42.

CSENDES LAJOS

1977 Történelem a térképeken. Lázár deák térképétől a részletes katonai felmérésekig. Hadtörténelmi Közlemények (Budapest) 24:2, 103-130. 
DAVIDOVICS KRISZTINA

2006 A halálbüntetés végrehajtásának liturgikus elemei - A hóhér. Mezey B. (szerk.): Jogi kultúrák, procesz-

DEAN, TREVOR szusok, rituálék és szimbólumok. Budapest, 46-64.

2007 Crime and Justice in Late Medieval Italy. Cambridge.

DESCHLER-ERB, SABINE-STOPP, BARBARA

2006 Die Tierskelette vom Wasenplatz am Letzigraben in Zürich-Albisrieden. (18. Jahrhundert.) Archäologischer Untersuchungbericht zur Grabung 2006. Stadt Zürich. Archäologie und Denkmalpflege 2003-2006. Internetpublikation. https://www.stadt-zuerich.ch/content/dam/stzh/hbd/Deutsch/ Archaeologie_Denkmalpflege/Publikationen\%20und\%20Broschueren/Online-Publikationen/2006_ Deschler_Stopp_LetzigrabenTierskelette.pdf. [letöltés: 2017. január 21.]

DUMA, PAWEL

2010 Grób alienata. Pochówki dzieci nieochrzczonych, samobójców i skazańców w późnym średniowieczu wczesnonowoźytnej (Die Greben den Entfremdeten-Begräbnisse von Ungetauften Kindern). Selbsmördern, und Verurteilten im Späten Mittelalter und der Frühen Neuzeit. Kraków.

2015 Śmierć nieczysta na Śląsku. Studia nad obrządkiem pogrzebowym społeczeństwa przedindustrialnego. (Profane death in Silesia. A study of funeral practices of the pre-industrial society). Wrocław.

DÜLMEN, RICHARD

1990 A rettenet színháza. Ítélkezési gyakorlat és büntetőrituálék a kora újkorban. Budapest.

EVERS, THIERS

2008 Richstätten in zeitgenössischen Bildquellen. Typologie und Topographie. Auler, J. (Hrsg.): Richstättenarchäologie. Dormagen, 444-465.

GARDELA, LESZEK-KAJKOWSKI, KAMIL

2013 Vampires, Criminals, or Slaves? Reinterpreting 'Deviant Burials' in Early Medieval Poland. World

GENESIS, MARITA Archaeology 45:5, 780-796.

2008 Der Rabenstein in Erfurt. Eine mittelalterliche/frühneuzeitliche Richstätte in historischen und archäologischen Quellen. In: Auler, J. (Hrsg.): Richstättenarchäologie. Dormagen, 144-150.

GRÓF PÉTER

2003 Visegrád-Várkert. Kisfaludi J. (szerk.): Régészeti kutatások Magyarországon 2000 (Archaeological investigations in Hungary 2000). Budapest, 232-233.

GYULAI ÉVA

1999 A Tetemvár Miskolc XVI-XIX. századi topográfiájában. Fából és deszkából. A miskolci Deszkatemplom. Miskolc, 141-185.

2000 Topográfia és városkép. Miskolc története III/1. 1702-1847-ig. Miskolc, 57-151.

HAJDU LAJOS

1985 Búntett és büntetés Magyarországon a XVIII. század utolsó harmadában. Budapest.

JAKAB ATTILA

2009 Hóhérpallos a nyíregyházi Jósa András Múzeumban. Szabolcs-Szatmár-Beregi Szemle 44:3, 377-383.

JANKOVICH MiKLÓs

1963 Újlak és Szentjakabfalva helyrajzi adatai az 1702. évi Zaiger tükrében. Budapest Régiségei (Budapest) 20, 155-164.

JANKÓ ANNAMÁRIA

2001 A második katonai felmérés. Hadtörténelmi Közlemények 114:1, 103-130.

KAJTÁR ISTVÁN

2004 Bevezetés a jogi kultúrtörténetbe. Budapest-Pécs, 2004.

2006 Jogi kultúra, jogi szimbólumok és rítusok. In: Mezey B. (szerk.): Jogi kultúrák, processzusok, rituálék és szimbólumok. Budapest, 130-145.

KÁLLAY ISTVÁN

1974 Székesfehérvár kiváltságlevelei. Fejér Megyei Történeti Évkönyv (Székesfehérvár) 8. Tanulmányok és források Fejér megye történetéhez 10, 149-201.

KELLER, ALBRECHT

1921 Henker/Blutvogt, Carnifex. Der Scharfrichter in der deutschen Kulturgeschichte. Bonn und Leipzig, 1921.

KERTÉSZ RÓBERT

2012 Fejezetek a török kori Szolnok kutatástörténetéhez és egy újabb azonosított objektum: a vesztőhely. Szolnoki Tudományos Közlemények (Szolnok) 16, 40-64.

KRABATH, STEFAN

2008 Zwei Richtplätze in der Oberlausitz - eine seltene archäologische Denkmalgattung. Dormagen, 496-506.

Auler, J. (Hrsg.): Richstättenarchäologie. Dormagen, 152-167. 
KovalovszKi JÚLia

1980a Jelentés a Visegrád-Várkertben végzett ásatásról. 1980. október 21. Kézirat. Mátyás Király Múzeum, Adattár. Visegrád.

1980b Ásatási napló. Visegrád-Várkert, 1980. Kézirat, Mátyás Király Múzeum, Adattár. Visegrád.

KUBINYI ANDRÁS

2005 Késő középkori temetkezések a történeti forrásokban. Ritoók Á.-Simonyi E. (szerk.): „....a halál árnyékának völgyében járok..."A középkori templom körüli temetők kutatása. Opuscula Hungarica (Budapest) 6, 13-18.

LAVI, AIN

2008 Die mittelalterliche Hinrichtungstätte von Tallinn (Estland). In: Auler, J. (Hrsg.): Richstättenarchäologie. Dormagen, 106-110.

LÜCK, HEINER

2012 Was ist und was kann Rechtsarchäologie? Denkströme. Journal der Sächsischen Akademie der Wissenschaften zu Leipzig (Leipzig) 8, 35-55.

MADAS JÓZSEF

1977 A 17-19. századi pécsi vesztőhely. A Janus Pannonius Múzeum Évkönyve (Pécs) 22, 285-286.

1980 A pécsi vesztőhelyről. A Janus Pannonius Múzeum Évkönyve (Pécs) 25, 231-233.

MAISEL, WITOLD 1993 Rechtsarchäologie Europas. Wien.

MašKovÁ, PAVLínA-MicháLEK, JAN

2006 Archeologický výzkum v poloze „Na šibenici“ ve Vodňanech (okres Strakonice). Př́spěvek k archeologii popravišt́ v Čechách. Archäologische Grabung in der Flur „Na šibenici“ („Am Galgen”) bei Vodňany (Bezirk Strakonice). Ein Beitrag Zur Archäologie der Hinrichtungsstättenin Böhmen. Archeologické rozhledy (Praha) 55, 790-809.

MEZEY BARNA

2007 A büntetőjogi intézmények története a kezdetektől a polgári átalakulásig. In: Mezey B. (szerk.): Magyar jogtörténet. Budapest, 263-311.

2010 Régi idók tömlöcei. Büntetések, börtönök, bakók. Budapest.

Mezey Barna-NAgY JANKa TeOdóRa (szerk.)

2009 Jogi néprajz - jogi kultúrtörténet. Tanulmányok a jogtudományok, a néprajztudományok és a történet-

MoRDOVIN MAXIM tudományok köréből. Budapest.

2016 Előzetes jelentés a Pápa, Fő téren végzett megelőző feltárások második és harmadik üteméről. In: Kisfaludi J. (szerk.): Régészeti kutatások Magyarországon 2011-2014 (Archaeological investigations in Hungary 2011-2014). Budapest, 232-233.

Motschi, ANDREAS-Muntwyler, Christian-LANGenegGer, Elisabeth-Deschler-Erb, SABINE-STopp, Barbara

2008 Hochgericht und Wasenplatz von Zürich Albisrieden. Ergebnisse der archäologischen, antropologischen und archäozoologischen Untersuchungen 2006. Auler, J. (Hrsg.): Richstättenarchäologie. Dormagen, 206-230.

MRT 9

1993 Dinnyés István-Kóvári Klára-Kvassay Judit-Miklós Zsuzsa-Tettamanti Sarolta-Torma István: Pest megye régészeti topográfiája (XIII/2.). A szobi és váci járás. Torma I. (főszerk.): Magyarország Régészeti Topográfiája 9. Budapest.

MVA 1

2010 Jankó Ferenc-Kücsán József-Szende Katalin (Dávid Ferenc-Goda Károly-Kiss Melinda közremúködésével): Magyar Várostörténeti Atlasz 1. (Hungarian Atlas of Historical Towns No. 1.) Sopron.

NAGY JÓZSEF

1876 A cholera Nyitra megyében 1831-tól 1874-ig. Nyitra.

NAGY TIBOR

1943 A Fővárosi Régészeti és Ásatási Intézet jelentése az 1938-1942. évek között végzett régészeti kutatásairól. Budapest Régiségei 13 (Budapest) 359-399.

NÁNÁSI LÁSZLÓ

2012 A magyar történeti büntetésügyi tudomány megteremtőjének, Vajna Károlynak élete és múve. Jogtörténeti Szemle (Budapest) 2012:1, 26-35.

NEMES LAJOS

2001 Eger város önkormányzata 1687-1848.Tanulmányok Heves megye történetéból 16. Eger.

OBTUŁOWICZ, ŁUKASZ-POKUTTA, DALIA A.

2014 The graves of criminals in Renaissance Poland. Archaeological excavations of Modern Age cemetery in

Pandula Attila

Gliwice Dworcowa Street, Upper Silesia. Śląskie Sprawozdania Archeologiczne (Wrocław) 56, 313-341.

1989 Kivégzés, tortúra és megszégyenítés a régi Magyarországon. Kiállítási katalógus. Eger. 
Piech, JAROSLAW

2008 „mit fliegenden Fahnen” zogen sie um Hochgericht: Der Galgen von Ellwangen an der Jagst 1701-1811. Auler, J. (Hrsg.): Richstättenarchäologie. Dormagen, 12-45.

PIEPER, PETER-SCHLÜTER, BRITTA

2008 Genagelte menschlice Schädel. Auler, J. (Hrsg.): Richstättenarchäologie. Dormagen, 388-412.

PLATT, COLIN

1976 The English Medieval Town. London.

PÓCZY KLÁRA

1994 Az aquincumi katonai amfiteátrum múemléki helyreállítása Óbuda városrendezési tervének forrásaként. Gerő László 85. születésnapjára. Tanulmányok. Múvészettörténet - Múemlékvédelem (Budapest) 6, 27-41.

REYNOLDS, ANDREW

2009 Anglo-Saxon Deviant Burial Customs. Oxford.

RÓZSA GYÖRGY

1996 Sopron látképeiről. Tanulmányok Csatkai Endre emlékére. A Soproni Múzeum Kiadványai (Sopron) 2, 201-207.

RózSA MiKLós

2003 A Kanizsai Városi Tanács pallosjoggal felruházása és a vesztőhely felállítása. Zalai Múzeum (Zalaegerszeg) 12, 209-214.

SIKLÓSI GYULA

2005 Egykori büntetés végrehajtó eszközök nyomai Körmenden. Körmendi Figyelő (Körmend) 13, 17-23.

SOKOL, PETR

2003 Šibenice v Bečově nad Teplou a archeologie popravišt'. The gallows at Bečov nad Teplou and the archeology of places of execution. Archeologické rozhledy (Praha) 55, 736-766.

2008a War, Town, Gallows. Some Aspects of Gallows on Historic Images. Auler, J. (Hrsg.): Richstättenarchäologie.

Dormagen, 49-505.

2008b The Gallows at Bečov nad Teplou, District of Karlovy Vary, Czech Republic Research, Conservation Presentation. Auler, J. (Hrsg.): Richstättenarchäologie. Dormagen, 250-269.

2010 Gallows and Beheading Places in Pilsen. On Using Pictorial, Cartographic, Written, and Archaeological Sources. Auler, J. (Hrsg.): Richstättenarchäologie 2. Dormagen, 348-374.

SZEGHYOVÁ BLANKA

2004 Erőszak és konfliktuskezelés a polgárok mindennapi életében a 16. században. Történelmi Szemle (Budapest) 46:1-2, 167-190.

SZÉKELY ZOLTÁN

2004 Nicolo Angielini 1566-os rajza Győr váráról és Miksa császár táboráról. Arrabona (Győr) 42:2, 167-183.

2006 Kép és valóság. Törökkori metszetes várábrázolások és forrásaik Győr példáján. XVI. század. A Castrum

Bene Egyesület 12. vándorgyúlése. A várkutatás írott és képi forrásai. Arrabona (Győr) 44:2, 131-174.

SZUROMI SZABOlCs ANZELM

2005 A templom körüli temetkezés a középkori egyházfegyelem tükrében (12-13. század). Ritoók Á.-Simonyi E. (szerk.): „....a halál árnyékának völgyében járok...” A középkori templom körüli temetők kutatása.

TEMESVÁRY FERENC Opuscula Hungarica (Budapest) 6, 9-12.

1970 Büntető eszközök a régi Magyarországon. A Jánosházai Múzeum Közleményei 1. Szombathely.

TÓTH ALBERT

1989 A Jászság kunhalmai. Zounuk. A Szolnok Megyei Levéltár Évkönyvei (Szolnok) 4, 419-440.

TÓTH J. ZOLTÁN

2006 A halálbüntetés szabályozása a középkorban, különös tekintettel a Német-Római Birodalomra. Jogtörténeti Szemle (Budapest) 2006:4, 68-75.

2007 A halálbüntetésre vonatkozó anyagi jogi szabályok a feudalizmus Magyarországán. Jogtörténeti Szemle (Budapest) 2007:4, 30-50.

2008 A halálbüntetés írottjogi szabályozása Magyarországon a felvilágosodástól a Csemegi-kódexig. De iuresprudentia et iure publico (Budapest) 2:3, 1-21.

2010 A halálbüntetés intézményének egyetemes és magyarországi jogtörténete. Budapest.

TRZCINSKI, MACIEJ

2001 Miecz katowski, pręgierz, szubienica: zabytki jurysdykcji karnej na Dolnym Śląsku (XIII-XVIII w.) Wrocław.

VAJNA KÁROLY

1906 Hazai régi büntetések. I. Budapest.

1907 Hazai régi büntetések. II. Budapest. 


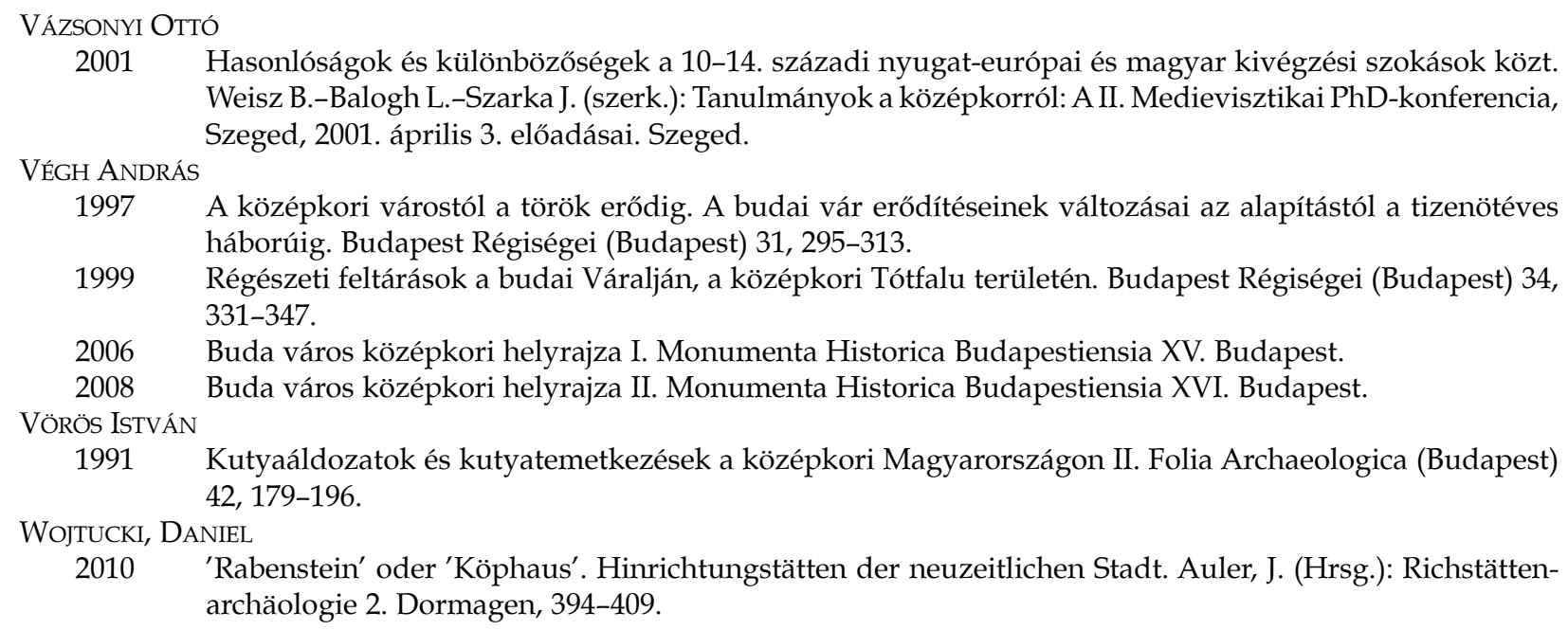

\section{THE ARCHAEOLOGY OF MEDIEVAL AND 16TH-18TH-CENTURY EXECUTION SITES IN EUROPE AND HUNGARY}

\section{ISTVÁN KovÁTS}

During the medieval and post-medieval period, capital punishment was a generally applied punishment type in every country. The number of offences and crimes against property and of violent crimes increased in the 16th-17th centuries; although to different extents in various areas and regions, public safety generally declined, explaining the dramatic increase in the period's capital sentences. Not only were crimes against life punished by death, but so were also several other offences (against property, morals, religion, etc.).

The goal of punishment and their public execution was to avenge crimes and to discourage future offences. The ultimate purpose of the public execution of judiciary sentences was essentially the same. The procedure gradually turned into a spectacular ceremony from the 17th century onward. While the overall system of corporeal punishment and the associated judiciary and execution rites began to be criticised in the 18th century, the Age of Enlightenment and of the transformation of criminal law, it remained the dominant form of punishment until the 19 th century in most European countries.

Similar tendencies as in Europe can be noted in Hungarian legal practice. The laws of King St. Stephen (r. 997-1038) institutionalised capital punishment in certain cases, while King St. Ladislaus (r. 1072-1095) extended capital punishment to certain types of thefts - still, it would seem that capital punishment was rarely applied in the 10th-13th centuries. Later, parallel to the legal tendencies in Europe, it became more widespread in Hungary too. In the 16th-17th centuries, the number of methods of capital punishment adopted from the German-Austrian legal practice and the number of executions increased significantly. Although the Tripartitum, the collection of customary law assembled by the Palatine István Werbőczy in 1514, had set down in writing the criminal acts punishable by death, it did not bring an end to the legal variability of the previous centuries. Regulations based on customary law were still alive as late as the 18th century, although less frequently from the century's later half. During the Age of Enlightened Absolutism, Hungarian legal practice regarding criminal offences became more humane, but executions performed on public execution sites (principally hangings and beheadings) are still known from the 19th century.

The archaeology of execution sites (Richstättenarchäologie) became an independent interdisciplinary research direction within post-medieval archaeology from the 1990s, principally in Western and Central Europe. The focus of this direction, which emerged from the archaeology of law and took its cues from that field, is not restricted to execution sites and their immediate vicinity in the strict sense. All finds and relics (such as the remains of pillories) that can be associated with, or have a relevance for, jurisdiction and carrying out sentences can be assigned here.

The excavation conducted by anthropologist Lajos Bartucz in 1914 with the aim of uncovering the burials of the Hungarian Jacobins who had been sentenced to death by beheading and identifying the bodies can be regarded as the antecedent of research on execution sites in Hungary (Fig. 1).

The gallows or the execution site was in the focal point of the ceremony of execution (Fig. 2), which together with the pillory symbolised a town's right to jurisdiction. These facilities could be located within the settlement (inter muros) or outside it (extra muros, extra civitatem). The wooden scaffold set up inside the settlement, usually in a central location, was generally a temporary affair. Permanent execution sites were generally located at the edge of the towns, usually in higher-lying places, within eyesight from the roads, crossroads and town gates (Fig. 3). At first, trees were used for hanging; later, sever- 
al variants of timber gallows evolved. Their mass construction and widespread use fell between the 16th and 18 th centuries. Permanent execution sites were generally 2-3 m high round or oval platforms with $80-120 \mathrm{~cm}$ walls and an external diameter of 5 to $7 \mathrm{~m}$ (Fig. 4). The gallows were placed on these platforms. One singular type of execution site was the raven stone (Rabenstein), which was mainly used for beheadings. The construction and maintenance of execution sites was a costly affair in some places, and it was the authorities' interest to erect a permanent execution site, which also demonstrated the might of the law and the power of the town council. The most prominent features of execution sites are the partial or full human skeletons, usually representing deviant burials (Fig. 5). The executed person's body was either buried at the execution site (beside it or underneath it), in a separate burial ground or in some other location separate from the community cemetery. The bodies or certain bodily parts were sometimes publicly displayed for a shorter or longer period of time, or they were destroyed either as part of the execution procedure (for example by burning and drowning) or afterwards.

Even though not one single execution site has yet been fully excavated and documented from medieval and 16th-18th-century Hungary, their existence is indicated by several types of sources (documentary sources, visual evidence in the form of depictions/maps and archaeological finds; Fig. 6).

Two damaged human skeletons and iron shackles recovered from a thin debris layer in the arena of the military amphitheatre of Aquincum can be regarded as the remains of an execution site used in the 18th century.

Five of the burials uncovered in an area known as Akasztófa-dúlő ["Gallows field"] near Vác can be associated with a post-medieval execution site.

A partial human burial and the skeletal remains of six dogs above and beside the human remains were found in a pit during the excavation of an early Árpádian Age settlement at Visegrád-Várkert (Fig. 8). The initial examina- tion of the remains identified cut marks on a part of the human and animal bones, which suggested that the assemblage dated to the 10th-11th centuries was a unique relic of a medieval execution mode, namely of quartering, while the burial with dogs was regarded as a form of humiliation. However, the re-examination of the remains, currently still in progress, does not support the earlier interpretation of quartering. The partial damage to the corpse can probably be ascribed to predatory animals. It would appear that the head had been severed from the body at the time of the burial and there were also blow marks on some of the bones. Still, these relics can be associated with the execution of punishment, although further analyses are necessary for a conclusive interpretation.

Six irregular 18th-century burials were found at 20 Zichy Street in Vác, beside the former town wall of the one-time German town (Figs 9-10). Animal remains, perhaps of dogs, were found in and beside the graves. Since no traces of a church or a cemetery are known from the area, it was assumed that the persons buried here without a coffin, dress accessories or any other grave goods had probably been outlaws or social outcasts, or perhaps persons who had been executed.

The remains of two 18th-century pillories were identified on Széchenyi Square in Győr (Fig. 11).

Two rectangular structures with a brick foundation functioning as the town's pillory were built on Fó Square in Pápa during the square's 18th-century reconstruction (Fig. 12). The bricks stamped with the year 1751 provided the exact date of the construction.

Although the ius gladii of the seigneurial courts in Hungary had been revoked by Emperor Joseph II, it was only finally abolished in 1848 . In the earlier 19th century, incarceration became the main form of punishment instead of public corporeal punishment and the death penalty. During this period, the very sight of execution places roused feelings of outrage and compassion. In the 1850s, most of the execution sites that had since long stood on the outskirts of towns were demolished. 